\title{
Abundance and physiology of dominant soft corals linked to water quality in Jakarta Bay, Indonesia
}

\author{
Gunilla Baum ${ }^{\text {Corresp.. }}{ }^{1,2}$ ， Indra Januar ${ }^{3}$ ， Sebastian CA Ferse ${ }^{1}$, Christian Wild $^{2}$ ， Andreas Kunzmann ${ }^{1}$ \\ 1 Department of Ecology, Leibniz Center for Tropical Marine Ecology, Bremen, Germany \\ 2 Faculty of Biology and Chemistry, University of Bremen, Bremen, Germany \\ 3 Indonesian Research Center for Marine and Fisheries Products Processing and Biotechnology, Jakarta, Jakarta Pusat, Indonesia \\ Corresponding Author: Gunilla Baum \\ Email address: gunilla.baum@gmail.com
}

Declining water quality is one of the main reasons of coral reef degradation in the Thousand Islands off the megacity Jakarta, Indonesia. Shifts in benthic community composition to higher soft coral abundances have been reported for many degraded reefs throughout the Indo-Pacific. However, it is not clear to what extent soft coral abundance and physiology are influenced by water quality. In this study, live benthic cover and water quality (i.e. dissolved inorganic nutrients (DIN), turbidity, and sedimentation) were assessed at three sites ( $<20 \mathrm{~km}$ north of Jakarta) in Jakarta Bay (JB) and five sites along the outer Thousand Islands (20-60 km north of Jakarta). This was supplemented by measurements of photosynthetic yield and, for the first time, respiratory electron transport system (ETS) activity of two dominant soft coral genera, Sarcophyton spp. and Nephthea spp. Findings revealed highly eutrophic water conditions in JB compared to the outer Thousand Islands, with 44\% higher DIN load $(7.65 \mu \mathrm{M} / \mathrm{L}), 67 \%$ higher turbidity (1.49 NTU) and $47 \%$ higher sedimentation rate $\left(30.4 \mathrm{~g} \mathrm{~m}^{-2} \mathrm{~d}^{-1}\right)$. Soft corals were the dominant type of coral cover within the bay ( $2.4 \%$ hard and $12.8 \%$ soft coral cover) compared to the outer Thousand Islands (28.3\% hard and $6.9 \%$ soft coral cover). Soft coral abundances, photosynthetic yield, and ETS activity were highly correlated with key water quality parameters, particularly DIN and sedimentation rates. The findings suggest water quality controls the relative abundance and physiology of dominant soft corals in JB and may thus contribute to phase shifts from hard to soft coral dominance, highlighting the need to better manage water quality in order to prevent or reverse phase shifts. 


\section{Abundance and physiology of dominant soft corals linked to water quality in Jakarta Bay, Indonesia \\ 3 \\ 4 \\ 5 6 \\ Gunilla Baum $^{1,2}$, Indra Januar ${ }^{3}$, Sebastian CA Ferse $^{1}$, Christian Wild ${ }^{2}$, Andreas Kunzmann ${ }^{1}$ \\ ${ }^{1}$ Department of Ecology, Leibniz Center for Tropical Marine Ecology (ZMT) Bremen GmbH, Bremen, Germany \\ 2 Faculty of Biology and Chemistry, University of Bremen, Germany \\ ${ }^{3}$ Indonesian Research Center for Marine and Fisheries Products Processing and Biotechnology, Jakarta Pusat, Indonesia}

\section{Corresponding author:}

Gunilla Baum

Department of Ecology, Leibniz Center for Tropical Marine Ecology (ZMT) Bremen GmbH, Fahrenheitstraße 6, 28359 Bremen, Germany

E-mail: gunilla.baum@gmail.com (GB) 


\section{Abstract}

Declining water quality is one of the main reasons of coral reef degradation in the Thousand Islands off the megacity Jakarta, Indonesia. Shifts in benthic community composition to higher soft coral abundances have been reported for many degraded reefs throughout the Indo-Pacific. However, it is not clear to what extent soft coral abundance and physiology are influenced by water quality. In this study, live benthic cover and water quality (i.e. dissolved inorganic nutrients (DIN), turbidity, and sedimentation) were assessed at three sites $(<20 \mathrm{~km}$ north of Jakarta) in Jakarta Bay (JB) and five sites along the outer Thousand Islands (20-60 km north of Jakarta). This was supplemented by measurements of photosynthetic yield and, for the first time, respiratory electron transport system (ETS) activity of two dominant soft coral genera, Sarcophyton spp. and Nephthea spp. Findings revealed highly eutrophic water conditions in JB compared to the outer Thousand Islands, with 44\% higher DIN load (7.65 $\mu \mathrm{M} / \mathrm{L}), 67 \%$ higher turbidity (1.49 NTU) and 47\% higher sedimentation rate $\left(30.4 \mathrm{~g} \mathrm{~m}^{-2} \mathrm{~d}^{-1}\right)$. Soft corals were the dominant type of coral cover within the bay $(2.4 \%$ hard and $12.8 \%$ soft coral cover) compared to the outer Thousand Islands $(28.3 \%$ hard and $6.9 \%$ soft coral cover). Soft coral abundances, photosynthetic yield, and ETS activity were highly correlated with key water quality parameters, particularly DIN and sedimentation rates. The findings suggest water quality controls the relative abundance and physiology of dominant soft corals in JB and may thus contribute to phase shifts from hard to soft coral dominance, highlighting the need to better manage water quality in order to prevent or reverse phase shifts.

\section{Introduction}

Coral reefs worldwide are characterized by a considerable loss in coral cover and species diversity (Bellwood et al., 2004; Bruno \& Selig, 2007). The degradation of coral reefs is often related to declining water quality linked to eutrophication and pollution as a result of urban runoff, which carries large amounts of domestic wastes and industrial effluents (Fabricius, 2005; van Dam et al., 2011). Eutrophication has been proposed as the main stress factor for many reefs worldwide (GESAMP, 2001). For example, long term monitoring data from the Great Barrier Reef show that the overall reduction in total coral cover by $70 \%$ is mainly due to eutrophication (Bell, Elmetri \& Lapointe, 2014).

A growing body of literature suggests that the degradation of coral reefs is often associated with shifts in the benthic community to new compositions (e.g. Done, 1982; Hughes, 1994). Phase shifts on coral reefs are usually associated with shifts from hard coral-dominated to macroalgaedominated communities (Nyström, Folke \& Moberg, 2000; Szmant, 2002; Hughes et al., 2007). However, shifts to reefs dominated by other benthic organisms such as sponges, 
corallimorpharians, zoantharians and soft corals have been reported as well (Chou \& Yamazato, 1990; Fox et al., 2003; Ward-Paige et al., 2005). To date, these shifts have received less attention, and the underlying mechanisms are still poorly understood (Norström et al., 2009). Soft corals (Octocorallia) represent a diverse and widespread benthic group within coral reefs in the Indo-Pacific (Dinesen, 1983; Benayahu, 1997; Benayahu et al., 2004) and are important for reef structure and function (Cary, 1931). Studies on coral-macroalgae shifts suggest that those shifts are caused by loss of top-down control as a result of overfishing (Hughes et al., 2007; Rasher et al., 2012). In contrast, phase shifts to sponges, corallimorpharians and soft corals may be driven by bottom-up control and soft corals may be driven by bottom-up control and reduction in water quality (Holmes et al., 2000; Norström et al., 2009). However, the literature is unclear whether soft corals are more tolerant towards declining water quality compared to hard corals (Dinesen, 1983; Fabricius \& De'ath, 2004). For instance, Fabricius and De'ath (2004) found that soft coral species richness declined up to $60 \%$ along a gradient of increasing turbidity, while other studies found a higher tolerance of soft corals towards high sedimentation rates (McClanahan \& Obura, 1997). In addition, there is considerably more knowledge available on hard-coral physiology than for soft corals, for instance on how the metabolism of soft corals is influenced by anthropogenic stress and whether soft corals react differently than hard corals on a physiological level. Such knowledge is however crucial to understand the conditions, such as for example reduced water quality, and underlying mechanisms that drive phase shifts to soft coral dominance, and is needed to improve management strategies for coral reefs (Folke et al., 2004). Two promising indicators for metabolic stress responses in marine organisms to declining water quality are the photosynthetic capacity and electron transport system (ETS) activity (Jones, Kildea \& Hoegh-Guldberg, 1999; Fanslow, Nalepa \& Johengen, 2001; Lesser, 2013; Maes et al., 2013). Photosynthetic capacity can be determined though the quantum yield of linear electron transport (i.e. photosynthetic yield $=$ delta F/Fm'). ETS activity has been mainly used as an indicator for metabolic condition in zooplankton (Båmstedt, 1980; Gomez et al., 1996) and fishes (Ikeda, 1989; Lannig et al., 2003), but only few studies have used it for marine invertebrate species such as mussels (Fanslow, Nalepa \& Johengen 2001; Nahrgang et al., 2013), and to our knowledge no studies have measured ETS in corals. The ETS is a multi-enzyme complex in the respiratory chain in the mitochondria during which electrons are passed along numerous enzymes and energy is generated for oxidative phosphorylation and ATP synthesis. The synthesis and degradation of these macro-enzymes depends on the respiratory requirements of the organism and therefore by measuring ETS activity, a time-averaged value of the maximum oxygen uptake rate potential is given. Since ETS activity adjusts to changes in environmental conditions over several days and weeks, short-term fluctuations and experimental factors are less influential than for direct measurements of respiration (Båmstedt, 1980; Cammen, Corwin \& Christensen, 1990). Both ETS activity and photosynthetic yield can increase in organisms exposed to pollution to compensate for stress effects (i.e. produce more ATP) or decrease due to toxic effects (van Dam et al., 2011). 
116 With around 25 million inhabitants (Brinkhoff, 2011), the Greater Jakarta Metropolitan Area is 117 the 2nd largest urban agglomeration in the world (UN, 2014). Located in front of Jakarta Bay 118 (JB), the Kepulauan Seribu ("Thousand Islands") chain represents an ideal area to assess the

119

120

121

122

123

124

125

126

127

128

129

130

131

132

133

134

135

136

137

138

139

140

141

142

143

144

145

146

147

148

149

150

151

152

153

154 effects of multiple stressors on coral reef organisms. Various human-induced marine and coastal environmental problems such as high sediment load, water pollution, depletion of fishery resources, seafood contamination, loss of habitat, coastal littering as well as eutrophication have caused severe degradation of coral reefs in Jakarta Bay and the Outer Thousand Islands. Localized effects of anthropogenic stressors appear to have led to a spatial patchwork of differentially degraded reefs (Rachello-Dolmen \& Cleary, 2007; Baum et al., 2015). Although reefs within the bay once had thriving coral communities (Verstappen 1953; Arifin, 2004; van der Meij, Suharsono \& Hoeksema, 2010), they are now dominated by sand, rubble and algae, with a current hard coral cover of $<5 \%$ for nearshore reefs within JB. Mid- and offshore reefs along the Thousand Islands have highly variable reef conditions $(<20 \%$ hard coral cover to 50\%) (Cleary et al., 2014; Baum et al., 2015). Considering that coral reefs are of huge economic and environmental importance in the area, supporting fisheries and tourist sectors and providing habitats with high productivity and diversity, there is a growing need to understand coral reef functioning.

In order to increase our understanding of shifts towards soft coral dominance in reefs exposed to multiple anthropogenic stressors, this study aimed to answer the following research questions: 1) How does distance to Jakarta influence key water quality parameters? 2) How does distance to Jakarta (i.e. declining water quality) influence live benthic cover in local coral reefs and do hard or soft corals dominate? 3) Does water quality affect photosynthesis and ETS activity of two dominant soft coral genera in the area, Sarcophyton spp. (Family: Alcyoniidae) and Nephthea spp. (Family: Nephtheidae)? Which water quality parameters affect the metabolic condition of these soft corals? We hypothesize that closer to Jakarta a) water quality is reduced b) soft coral dominance of the living benthos occurs more frequently and c) the photosynthesis and ETS activity in soft corals are negatively affected by reduced water quality. In order to answer these questions, a combination of benthic surveys, water quality assessments, and physiological measurements were carried out.

\section{Material and Methods}

\section{Study area}

The Kepulauan Seribu (Thousand Islands) stretch up to $80 \mathrm{~km}$ north of Jakarta and are comprised of 105 small ( $<10 \mathrm{ha}$ ) and very low-lying ( $<3 \mathrm{~m}$ above sea level) islands (Arifin, 2004). Indonesia's first Marine National Park, the Thousand Islands National Park, was established in 1982 in the north of the island chain (Djohani, 1994). Most islands have lagoons and fringing reefs with reef development generally restricted to shallow depths (around 3-10 m, max. $20 \mathrm{~m}$ depth). The island chain is densely populated (total population: 22,700 people). 65\% of the people live on the four main islands Panggang, Pramuka, Kelapa and Harapan (BPS, 
155

156

157

158

159

160

161

162

163

164

165

166

167

168

169

170

171

172

173

174

175

176

177

178

179

180

181

182

183

184

185

186

187

188

189

190

191

192

2012). Several rivers with a combined catchment area of $2000 \mathrm{~km}^{2}$ discharge directly into Jakarta Bay and transport large amounts of untreated sewage and industrial effluents with high pollutant levels (Rees et al., 1999). The bay's shoreline has been modified extensively over the last decades due to massive urbanization, industrialization and infrastructural development in Jakarta (60\% of the shoreline) as well as due to agricultural or aquaculture developments (30\% of the shoreline) (Bengen, Knight \& Dutton, 2006). During the dry season, the predominantly south-easterly winds can cause polluted surface waters from the JB area to reach midshore reefs (definition see below), while during the wet season, north-westerly winds blow from offshore towards JB (Cleary, Suharsono \& Hoeksema, 2006). In November 2012 during the transition time between northwest and southeast monsoon, eight coral reef sites across the Thousand Islands chain were visited. Three sites within JB (nearshore area; $<20 \mathrm{~km}$ ) and five sites from the outer Thousand Islands (mid- and offshore area; 20-45 km and $>45 \mathrm{~km}$, respectively) were chosen to represent both inhabited and non-inhabited islands. Reefs from the northern side or north-eastern side of each island (except for Pari South: here, the south side was included to account for the observed strong differences in coral cover between the northern and southern side of the island; (Abrar \& Zamani, 2011; Madduppa et al., 2012) were visited to ensure consistent wave exposure and current regimes (see Moll \& Suharsono, 1986; Cleary, Suharsono \& Hoeksema, 2006) (Table 1, Fig. 1).

\section{Live benthic cover}

Live benthic cover was determined at each site with 50 m line-intercept transects $(\mathrm{n}=3)$ at $5+/$ $0.5 \mathrm{~m}$ water depth (English, Wilkinson \& Baker, 1994). Every two meters, on both sides of the transect line, high-resolution underwater photographs $\left(n=50\right.$ transect $\left.^{-1}\right)$ were taken using a digital camera (Canon G12). A 1x1 m gridded quadrat frame was used for reference. These photographs were analyzed using CPCe software (Kohler \& Gill, 2006) with 50 random points placed on each photo (Brown et al., 2004), and each point was assigned to one the following benthic categories: hard corals, Nephthea spp., Sarcophyton spp., other soft corals and macroalgae. Since corals are the principal structure-providing benthic organisms and the loss of this structure results in reduced diversity and functionality of the ecosystem (Stanley, 2003; Munday, 2004), the survey focused on corals. Overall total live coral cover was calculated as the sum of hard and soft coral cover. A detailed description of the survey as well as further data on other substrate types including sand, rubble and dead corals as well as macroalgae is given in Baum et al. (2015).

\section{Water quality}

Anthropogenic stressors that reflect the water quality in the JB/Thousand Islands reef complex (De`ath \& Fabricius, 2010; Fabricius et al., 2012) were determined at each sampling site. The water parameters temperature $\left({ }^{\circ} \mathrm{C}\right)$, dissolved oxygen $(\mathrm{DO} ; \mathrm{mg} / \mathrm{L}), \mathrm{pH}$, salinity (PSU), turbidity $(\mathrm{NTU})$ and $\mathrm{Chl} a(\mu \mathrm{g} / \mathrm{L})$ concentration of the water were measured at 1 and $3 \mathrm{~m}$ water depth, using a Eureka 2 Manta Multiprobe (Eureka Environmental Engineering, Texas, USA). Water 
193

194

195

196

197

198

199

200

201

202

203

204

205

206

207

208

209

210

211

212

213

214

215

216

217

218

219

220

221

222

223

224

225

226

227

228

229

230

231

232

samples for inorganic nutrient analyses (nitrite $\left(\mathrm{NO}_{2}\right)$, nitrate $\left(\mathrm{NO}_{3}\right)$, phosphate $\left(\mathrm{PO}_{4}\right)$, ammonia $\left(\mathrm{NH}_{3}\right)$ ) were taken at each sampling site at 1 and $4.5 \mathrm{~m}$ water depth. Dissolved inorganic nitrogen (DIN) is given as the sum of $\mathrm{NO}_{2}, \mathrm{NO}_{3}$ and $\mathrm{NH}_{3}$. Sedimentation rate was estimated by deploying sediment traps (as recommended by Storlazzi, Field \& Bothner, 2011) at 5+/- $0.5 \mathrm{~m}$ depth for 22 $+/-1 \mathrm{~h}$ at each site $(\mathrm{n}=5$ traps per site). For a detailed description of the sampling design and analysis of water parameters, refer to Baum et al. (2015).

\section{Photosynthetic yield and ETS activity of soft corals}

At each site, fragments ( $5-10 \mathrm{~cm}$ length) of the two soft coral genera, Sarcophyton spp. and Nephthea spp. (recently synonymized with Litophyton by Van Ofwegen (2016), see http://www.marinespecies.org/aphia.php?p=taxdetails\&id=205891), were sampled $(n=5)$ during SCUBA diving at $5 \mathrm{~m}$ water depth. These two soft coral genera were chosen due their high abundances along the island chain. At nearshore sites, a sufficient number in hard coral replicates was not available. Therefore, photosynthetic yield and ETS activity in hard corals could not be measured. Taxonomic identification in the field was performed based on Fabricius and Alderslade (2001) to genus, the lowest taxonomic level possible for field surveys. Fragments were always chosen with the same morphological appearance (e.g. the same color, type and length of tentacles, hardness, etc) in order to minimize the collection of different species within the genera. Sarcophyton spp. samples were separated from the two morphologically similarlooking soft coral genera Lobophytum and Sinularia by considering that Lobophytum and Sinularia have "fingering" surfaces and that Lobophyton is harder than Sarcophyton.

\section{Photosynthetic yield}

Coral samples were placed immediately in two $100 \mathrm{~L}$ black plastic boxes, one box for each of the soft coral genera, respectively. The boxes were filled with fresh seawater from the sampling site. The water was aerated, and temperature, salinity, dissolved oxygen and $\mathrm{pH}$ monitored with a WTW 340i Multiparameter system (WTW, Germany) at regular intervals. $30 \%$ of the water was exchanged every $30 \mathrm{~min}$. Corals were dark-adapted for $3 \pm 24$ hours by covering the boxes with a lid (mean light in the box [PAR] $=4.3$ PAR; measured with LI-COR Li400, Germany). Photosynthetic capacity was then determined by measuring the chlorophyll fluorescence of photosystem II (PS II), using a pulse-amplitude modulated fluorometer (DIVING-PAM, Walz, Germany). Photosynthetic yield (also called maximum quantum yield; $F_{v} / F_{m}$ ) (Walz, 1998) was measured by holding the sensor tip around 3-5 $\mathrm{mm}$ above the polyps (Rodolfo-Metalpa, Huot \& Ferrier-Pagès, 2008). Number of fragments per site for both genera was $n=7$, except for the sites Rambut (with $\mathrm{n}=6$ for Nephthea spp.), Ayer Besar and Bira (with n $=6$ for Sarcophyton spp.), and Congkak (with $\mathrm{n}=4$ for Sarcophyton spp.).

\section{Electron transport system (ETS) activity}

Prior to dark-adaptation for measurement of photosynthetic yield, tissues samples were taken from each coral fragment, placed in small $2 \mathrm{ml}$ glass vials and immediately stored in liquid 
233

234

235

236

237

238

239

240

241

242

243

244

245

246

247

248

249

250

251

252

253

254

255

256

257

258

259

260

261

262

263

264

$265 \mathrm{~V}_{\text {Aliquot: }}$

$266 \mathrm{~V}_{\text {Extract: }}$ :

$267 \mathrm{~m}_{\text {sample: }}$ :

268 R:

$\varepsilon$ :

d:

nitrogen, until they could be placed in a $-80{ }^{\circ} \mathrm{C}$ freezer. ETS activity was measured at ZMT in Bremen, Germany. Replicate number varied between the two genera: $\mathrm{n}=5$ for Nephthea spp. (except for the sites Untung Jawa, Rambut: $n=4$ and Pari North, Bira: $n=3$ ) and $n=4$ for Sarcophyton spp. (except for the sites Pari North, Congkak, Bira: $\mathrm{n}=3$ ). The soft coral tissue samples (always kept on ice between steps) were ground with a plastic mortar for $90 \mathrm{~s}$ in homogenization buffer ( $\mathrm{HOM}$; stored at $-20^{\circ} \mathrm{C}$ ) containing $1.5 \mathrm{mg} / \mathrm{ml}$ polyvinylpyrolidone (PVP), $75 \mu \mathrm{M}$ MgSO4 x $7 \mathrm{H} 2 \mathrm{O}$ and $0.2 \%$ Triton X-100 in $0.1 \mathrm{M}$ phosphate buffer, $\mathrm{pH} 8.5$ (following Owens \& King, 1975). ETS enzyme extracts were prepared in a 50-fold volume (w:v) of homogenization buffer. After $1 \mathrm{~min}$ of tissue lysis by ultrasonication (Bandelin, Sonopuls HD 3100 ), the homogenates were centrifuged for $10 \mathrm{~min}$ at $2^{\circ} \mathrm{C}$ and $1500 \mathrm{~g}$ (Eppendorf, $5804 \mathrm{R}$ ). The resulting supernatant was transferred into a sterile Eppendorf cup and stored on ice until analyses. ETS activities were determined the same day, following Lannig et al. (2003) with slight modifications. The final assay volume was adjusted to $1 \mathrm{ml}$ and the reaction mixture was prepared as follows in $1.5 \mathrm{ml}$ single use plastic cuvettes: $500 \mu \mathrm{l}$ assay buffer $(0.1 \mathrm{M}$ phosphate buffer, $\mathrm{pH} 8.5$; stored at $4{ }^{\circ} \mathrm{C}$ ) were mixed with $250 \mu$ INT-solution (8 mM INT (2-(4Iodophenyl)-3-(4-nitrophenyl)-5-phenyl-2H-tetrazolium chloride) in $0.1 \mathrm{M}$ phosphate buffer, $\mathrm{pH}$ 8.5, stored at $4{ }^{\circ} \mathrm{C}$ ) and $167 \mu \mathrm{NADH}$-solution (7.2 mM NADH with $0.2 \%$ Triton X-100 (v:v) in $0.1 \mathrm{M}$ phosphate buffer, $\mathrm{pH} 8.5$, prepared daily), stirred with a plastic stirrer and incubated for 5 min at $30{ }^{\circ} \mathrm{C}$ in a cooling-thermomixer (HLC, MKR 23) in the dark. The reaction was started by adding $150 \mu \mathrm{l}$ of sample homogenate to the assay mixture. Immediately afterwards, the increase in absorbance of ETS activity was measured at $490 \mathrm{~nm}$ for $5 \mathrm{~min}$ with a time interval of $15 \mathrm{~s}$ (applying the associated measuring software UV WinLab from Perkin Elmer) in a spectrophotometer (Perkin Elmer, Lambda 35). The resulting slope, calculated by subtracting the blank activity from sample activity, was further used to calculate enzymes activities. All samples were run in triplicate. ETS activity $\left[\mu \mathrm{mol} \mathrm{O} \mathrm{O}^{-1} \mathrm{~g}^{-1}\right]$ was calculated according to the equation (Lannig et al., 2003):

$$
\text { ETS - activity }\left[\mu \mathrm{molO}_{2} h^{-1} g^{-1}\right]=\frac{\Delta A \mathrm{~min}^{-1}}{\varepsilon \times d} \times \frac{V_{\text {Assay }}}{V_{\text {Aliquot }}} \times \frac{V_{\text {Extract }}}{m_{\text {sample }}} \times R \times 60
$$

$\Delta \mathrm{A} \min ^{-1}: \quad$ change in sample absorbance - change in blank absorbance per min

molar extinction coefficient of INTP Formazan $\left[15900 \mu 1 \mu \mathrm{mol}^{-1} \mathrm{~cm}^{-1}\right]$

269 Statistical analysis 
270 Differences among sites for any of the water quality parameters, benthic parameters or ETS

271

272

273

274

275

276

277

278

279

280

281

282

283

284

285

286

287

288

289

290

291

292

293

294

295

296

297

298

299

300

301

302

303

304

305

306

307

activity rates, and photosynthetic yields for each of the two different soft coral genera, were analyzed using one-way ANOVA. In addition, differences between JB and outer Thousand Islands for hard and soft coral cover, respectively, were tested for using one-way ANOVA. All data were checked for assumptions of normality and homogeneity of variances. In case assumptions were not fulfilled, a Kruskal Wallis test was performed instead. If significant effects were detected, pairwise comparisons with the post-hoc Student-Newman-Keuls test were performed to assess significant differences between individual factors.

Linear regression analysis was performed to test whether gradual in- or decreases could be found in ETS activity and photosynthetic yield as well as benthic factors along the distance gradient from Jakarta. In addition, ETS activity and photosynthetic yield as well as benthic factors were checked for linear correlation with each other and with water factors, respectively. Linear regression with one breakpoint (i.e. two linear segments) was used instead when it was found to yield a higher correlation. Univariate statistics were performed with SigmaPlot 12.5.

Multivariate statistics were performed using PRIMER-E software v.6 (Clarke \& Gorley, 2006). To account for different scales and units (Clarke and Ainsworth, 1993), the water factors $\mathrm{PO}_{4}$, $\mathrm{NH}_{4}, \mathrm{NO}_{3}$, turbidity and $\mathrm{Chl}$ were $\log +1$ transformed, followed by normalization of all water factors. All benthic factors were square root transformed (Clarke and Green, 1988). Bray-Curtis similarity matrices (Bray \& Curtis, 1957) were calculated for the metabolic condition (ETS activity and photosynthetic yield) of Sarcophyton spp. and Nephthea spp., as well as the benthic cover and a Euclidian distance similarity matrix for water data (Clarke \& Gorley, 2006). Distance-based redundancy analysis (dbRDA; Anderson, 2001) was used to visualize differences between sites. In addition, the role of individual stressors was assessed with the BEST routine (using the BioEnv procedure based on Spearman rank correlation; Clarke \& Warwick, 2001) to determine which of the water and benthic factors best explained the metabolic condition and cover of Sarcophyton spp. and Nephthea spp.

\section{Results}

\section{Live benthic cover}

Hard coral cover was $2 \pm 2 \%$ at nearshore sites and $28 \pm 11 \%$ at the outer Thousand islands (mean $\pm \mathrm{SD})$. The highest hard coral cover $(47 \pm 11 \%)$ was found at Pari North in the midshore area. At nearshore sites mean soft coral cover $(13 \pm 6 \%)$ was significantly higher than hard coral cover $(p=0.023)$. Average soft coral cover at the outer Thousand islands was $7 \pm 8 \%$. Bruno et al. (2009) use a cut-off set at more than 50\% cover of the dominant benthic taxa to define a phase shift. However, few reefs globally display such abundances (Hughes et al., 2010). Here we define "dominance" in terms of the category of corals (soft or hard) with the highest percent cover in relation to live benthic cover. Total coral cover was at all sites the largest group of live benthic cover (see Baum et al., 2015). Soft coral dominance occurred at all three nearshore sites. Sarcophyton spp. cover was significantly increased compared to Nephthea spp. cover at the two 
sites Rambut in JB and Panggang at the outer Thousand Islands $(p<0.05)$. Overall, soft coral cover along the Thousand Islands was highly patchy and mainly comprised of the genera Nephtheidae and Xeniidae as well as the family Alcyoniidae, of which nephtheids and alcyoniidids were dominating (see Table 2, Fig. 2).

Total soft coral cover did not show a significant linear trend with decreasing cover towards offshore, however the cover of Nephthea spp. significantly decreased towards north $(p=0.02)$. For Sarcophyton spp., no significant relation with distance to Jakarta could be found (Table 3). Macroalgae cover was significantly different among sites and seemed higher at nearshore sites (mean $6 \pm 5 \%$ ) as well as at Panggang (mean $7 \pm 5 \%$ ) compared to sites from the outer Thousand Islands, however post hoc analysis did not show significant differences among sites. Neither did macroalgae cover show a significant decrease towards offshore $(p=0.19)$ (see Fig. 2, Table 2).

\section{Water quality}

Most water parameters neither showed a clear separation of nearshore sites and sites from the outer Thousand Islands, nor a clear distance-based spatial pattern (i.e. with increasing distance to Jakarta), but rather localized patterns (see Baum et al. (2015) for further details). Water quality at nearshore sites in JB seemed generally worse than at sites from the outer Thousand Islands, with a $67 \%$ higher turbidity $(1.5 \pm 0.7 \mathrm{NTU}), 47 \%$ higher sedimentation rate $\left(30.5 \pm 0.4 \mathrm{~g} \mathrm{~m}^{-2} \mathrm{~d}^{-1}\right)$, $44 \%$ higher DIN load $(7.6 \pm 3.6 \mu \mathrm{M} / \mathrm{L})$ and Chl $a(9.5 \pm 4.5 \mu \mathrm{g} / \mathrm{L})$ levels in the bay (mean $\pm \mathrm{SD})$; results were however not significant for all sites from JB. For other water parameters, e.g. the concentration of $\mathrm{PO}_{4}$ and $\mathrm{NH}_{3}$, values decreased towards offshore, with one exception. They showed significantly higher levels at one single offshore site (Panggang) compared to all other sites $(p<0.05)$ (see Table 4$)$.

\section{Photosynthetic yield}

Average photosynthetic yield $\left(\mathrm{F}_{\mathrm{v}} / \mathrm{F}_{\mathrm{m}}\right)$ of Sarcophyton spp. $(0.7 \pm 0.1)$ and Nephthea $\mathrm{spp} .(0.7 \pm$ $0.1)$ did not differ between the two genera. Significant differences in photosynthetic yield between sites were found for both soft coral genera $(p<0.001)$. Subsequent post hoc analysis revealed for Sarcophyton spp. that all sites in JB were significantly different from almost all other sites from the outer Thousand Islands $(p<0.05)$. Overall, the yield increased for Sarcophyton spp. towards the north $(p=0.017)$. Post hoc analysis for Nephthea spp. revealed a similar trend, with the two sites furthest south in the Bay (AB, UJ) being significantly different from most sites from the outer Thousand Islands $(p<0.05)$. The photosynthetic yield of Nephthea spp. did however not significantly increase towards the north $(p=0.202)$ (Table 3, Fig. 3).

\section{ETS activity}

Average ETS-activity [ $\mu \mathrm{mol} \mathrm{O} \mathrm{h}^{-1} \mathrm{~g}^{-1}$ ] of Sarcophyton spp. (25.8 \pm 8.5$)$ and Nephthea spp. (24.1 \pm 6.8 ) did not differ between the two genera. Significant differences in ETS-activity among sites were found for Nephthea spp. $(p=0.005)$ and Sarcophyton spp. $(p=0.009)$. Subsequent post hoc 
347

348

349

350

351

352

353

354

355

356

357

358

359

360

361

362

363

364

365

366

367

368

369

370

371

372

373

374

375

376

377

378

379

380

381

382

383

analysis revealed for both genera that the two sites $\mathrm{AB}$ and UJ in JB were significantly different from the midshore site PN with the highest ETS-activity (Table 3, Fig. 4).

\section{Correlations between soft coral physiology and environment}

The metabolic condition (indicated by photosynthetic yield and ETS) of both Sarcophyton spp. and Nephthea spp. was highly correlated with the overall water quality, with $79 \%$ of the variation in Nephthea spp. being explained by the three water parameters $\mathrm{PO}_{4}, \mathrm{NH}_{3}$ and temperature, and $68 \%$ of the variation in Sarcophyton spp. being explained by the three water parameters DO, $\mathrm{pH}$ and temperature. The correlation of the metabolic condition of both soft coral genera to live benthic cover was less significant, with $12 \%$ for Nephthea spp. and $6 \%$ for Sarcophyton spp. respectively. Along the Thousand Islands, $71 \%$ of overall live benthic cover could be linked to the water parameters $\mathrm{NH}_{3}, \mathrm{NO}_{2}$ and turbidity. 39\% of variation in the composite cover of both Sarcophyton spp. and Nephthea spp. could be explained by the differences in sedimentation rate and $\mathrm{NH}_{3}$ (see Table 5).

The correlation of metabolic condition with water parameters as well as with benthic composition is visualized in Fig. 5 and shows a similar pattern for both genera. Sites however did not separate according to their distance to Jakarta, with the midshore site PN separated from the other sites and the nearshore site AB (see Fig. 5).

Photosynthetic yield of Sarcophyton spp. was significantly lower at sites with elevated sedimentation rates $(p=0.004)$ and $\mathrm{NO}_{2}(p=0.007)$. ETS activity of Nephthea spp. was significantly lower at sites with elevated levels of DIN $(p=0.023), \mathrm{NH}_{3}(p=0.017)$ and $\mathrm{PO}_{4}(p$ $=0.009)$ as well as at higher temperatures $(p=0.038)$. The cover of Nephthea spp. was significantly higher at sites with higher Chl $a(p=0.0029)$ and sedimentation rate $(p=0.014)$. Furthermore, at sites with a higher cover of Nephthea spp. a significantly higher photosynthetic yield of Nephthea spp. was measured ( $p=0.018)$. Total soft coral cover was significantly higher at sites with higher Chl $a$ concentrations $(p=0.039)$ (see Table 3).

\section{Discussion}

Our findings suggest that water quality controls photosynthetic efficiency and ETS activity of dominant soft corals in Jakarta Bay, as well as the abundance of Nephthea spp. respectively. Findings revealed extremely eutrophic water conditions and overall dominance of soft corals within the bay compared to the outer Thousand Islands. Results indicate that both photosynthetic yield and ETS activity of the two common Indo-Pacific soft corals Sarcophyton spp. and Nephthea spp. were reduced in the bay and highly correlated with key water quality parameters, especially inorganic nutrient concentrations and sedimentation rates.

\section{Abundance of Sarcophyton spp. and Nephthea spp.}


384 The reef condition along the Thousand Islands at shallow depths can be considered as being poor

385

386

387

388

389

390

391

392

393

394

395

396

397

398

399

400

401

402

403

404

405

406

407

408

409

410

411

412

413

414

415

416

417

418

419

420

421

422

423 since total coral cover in most of the sites was $<25 \%$ (threshold based on Gomez \& Yap, 1988). Especially in the bay, the loss in coral cover is highly dramatic, with a current cover below $5 \%$. Currently, the highest hard coral cover can be found at midshore sites (47\%), with a subsequent significant decrease towards offshore (mean cover: 17 - 30\%) (data based on Baum et al., 2015). A similar pattern in hard coral cover along the distance gradient from the mainland was also observed by Cleary et al. (2014) for the Thousand Islands chain.

In this study, results indicate that soft coral dominance occurred at more sites within the bay than at the outer Thousand Islands. Within the bay, a mean cover of $2 \%$ hard and $13 \%$ soft corals was found compared to the outer Thousand Islands, where mean hard coral cover was $28 \%$ and that of soft corals was 7\%. Overall, the cover of Nephthea spp. was significantly higher in JB compared to the outer Thousand Islands and decreased towards offshore, while the cover of Sarcophyton spp. generally was also higher within JB, but overall displayed a patchier distribution with very high abundances at the site Rambut in JB and at the offshore site Panggang.

\section{Water quality}

Coral reefs along the Thousand Islands are exposed to numerous anthropogenic stressors that affect reefs both on regional and local scales (Zaneveld \& Verstappen, 1952; DeVantier et al. 1998; Berkelmans et al., 2004; Selig et al., 2006; Burke et al., 2012). Findings from Baum et al. (2015) and this study reconfirm that the water quality is substantially decreased within the bay, with extremely eutrophic conditions compared to the outer Thousand Islands. In $\mathrm{JB}, \mathrm{PO}_{4}$ levels reached $4 \mu \mathrm{M} / \mathrm{L}$ and DIN levels up to $13 \mu \mathrm{M} / \mathrm{L}$. Other studies have reported similarly high values for eutrophication along the Thousand Islands, e.g. DIN levels of up to $21 \mu \mathrm{M} / \mathrm{L}$ (Ladwig et al. 2016) and total nitrogen of $54 \mu \mathrm{M} / \mathrm{L}$ as well as total phosphate levels of $5.2 \mu \mathrm{M} / \mathrm{L}$ (Van der Wulp et al. 2016). This extreme eutrophication may be the consequence of massive land runoff, lack of sewage treatment and large-scale agri- and aquaculture in the area. Along the Thousand Islands, overall Chl $a$ levels (mean: $1.7 \mu \mathrm{g} / \mathrm{L}$ ) were above the eutrophication threshold level of $0.2-0.3 \mu \mathrm{g} / \mathrm{L}$ (Bell, Lapointe \& Elmetri, 2007) at all sites. Other significant stressors include increased sedimentation and turbidity rates. Sites within JB on average had a $47 \%$ higher sedimentation rate compared to offshore sites in the Thousand Islands, with up to $30 \mathrm{~g} \mathrm{~m}^{-2} \mathrm{~d}^{-1}$. There is however no clearly visible nearshore-offshore gradient in water quality. Along the outer Thousand Islands, water quality among sites is variable due to locally increased concentrations especially of inorganic nutrients at specific offshore sites, such as for example at Panggang, where $\mathrm{PO}_{4}, \mathrm{NH}_{3}$ and DIN concentrations peaked (see Baum et al., 2015).

Results from this study indicate that along the Thousand Islands, the live benthic cover composition was significantly related to anthropogenically-influenced water parameters. $71 \%$ of the variation in live benthic cover along the complete island chain could be linked to factors related to terrestrial run-off and eutrophication, especially $\mathrm{NH}_{3}, \mathrm{NO}_{2}$ and turbidity. One of the main stress factors for coral reefs worldwide is eutrophication (Bell, Elmetri \& Lapointe, 2014). 
424 Elevated concentrations of dissolved inorganic nutrients can reduce calcification rates in corals 425 (Loya, 2004) and increase macroalgae cover (Stimson \& Larned, 2000), thereby causing a 426 decline in hard coral cover (see review by Fabricius, 2005).

427

428

429

430

431

432

433

434

435

436

437

438

439

440

441

442

443

444

445

446

447

448

449

450

451

452

453

454

455

456

457

458

459

460

461

462

\section{Physiology of Sarcophyton spp. and Nephthea spp.}

Findings revealed that both photosynthesis and ETS activity of both soft coral genera were reduced in the bay. ETS activity and photosynthetic yield values measured in this study were comparable to those measured by other authors for different marine invertebrate species (Muscatine et al., 1984; Fanslow, Nalepa \& Johengen, 2001; Ulstrup et al., 2011; Nahrgang et al., 2013).

For both Sarcophyton spp. and Nephthea spp., a relatively high correlation between their metabolic condition (indicated by photosynthesis and ETS activity) and the overall water quality was found. $79 \%$ of the variation in metabolic condition of Nephthea spp. was explained by $\mathrm{PO}_{4}$, $\mathrm{NH}_{3}$ and temperature, and $68 \%$ by DO, $\mathrm{pH}$ and temperature for Sarcophyton spp. Similarly, the cover of these two soft coral genera was linked to eutrophication-related stressors. The combined cover of both Sarcophyton spp. and Nephthea spp. along the whole island chain was explained to $40 \%$ by the water parameters sedimentation rate and $\mathrm{NH}_{3}$, with a generally higher cover at nearshore sites, especially of Nepththea spp.

To our knowledge, this is the first study measuring ETS activity in soft corals. We found reduced ETS levels in both genera at two nearshore sites characterized by high nutrient and sedimentation levels. The ETS activity of Nephthea spp. was significantly lower at increasing levels of DIN and significantly linked to changes in temperature. Several studies have proposed ETS activity as a useful complementary indicator of long-term metabolic activity, as it provides valuable information on the physiological status of organisms (Fanslow, Nalepa \& Johengen, 2001; Nahrgang et al., 2013). Here, ETS activity was clearly linked to reduced water quality and indicates that ETS could be a useful stress indicator in soft corals.

Since both photosynthesis and ETS activity were highly negatively correlated with overall water quality, these results suggest a strong stress reaction towards the environmental conditions within the bay. Several other studies have reported decreased photosynthetic yields in corals affected by high levels of dissolved inorganic and particulate organic nutrients as well as turbidity and sedimentation (e.g. Marubini, 1996). This could explain why photosynthetic yield and respiration, as indicated by ETS activity in this study, were lowest at the most eutrophic and turbid sites in this study. Metabolic condition of the two soft coral genera did however not increase linearly towards offshore, and thus did not reflect the distance to Jakarta and the improved water quality towards offshore. This may be due to a lack in a clear nearshore-offshore gradient in water quality as a result of locally increased concentrations of especially inorganic nutrients at specific offshore sites.

\section{Correlation between water quality and soft coral cover}


463 Even though both Sarcophyton spp. and Nephthea spp. seem to be negatively affected by the 464 reduced water quality in the bay, they occurred more frequently in the bay than hard corals. 465 Heterotrophic filter-feeders such as many soft corals have been shown to benefit more from 466 dissolved inorganic and particulate organic nutrients than hard corals (Fabricius \& Dommisse, 467 2000; Fabricius, 2011). In areas of high particulate organic matter (POM), an important food 468 source for soft corals (Fabricius \& Dommisse, 2000), and elevated nutrient levels such as in JB, 469 some soft corals can increase their heterotrophic feeding rates and thereby compensate for energy losses resulting from light reduction due to increased turbidity. They may therefore be able to outcompete hard corals that thrive better in extremely low food and nutrient environments. Thus, soft coral dominance may be the result of release from competition with stony corals driven by water quality, particularly by eutrophication and sedimentation, and could be facilitated at nearshore sites in JB. Nonetheless, in order to find out why both Sarcophyton spp. and Nephthea spp. are generally more abundant in JB, even though their metabolic conditions seem to be impaired, further investigations are required. It may be possible that hard corals in the area are more affected by the low water quality compared to soft corals. In order to assess whether soft corals are relatively better in tolerating the low water quality in the bay compared to hard corals, which could facilitate their dominance in the bay, comparable data on physiological responses of hard corals at the same study sites are needed. Further knowledge on the effects of declining water quality on the physiology of soft and hard corals such as growth rates, pigment concentrations as well as

483 484

485

486

487

488

489

490

491

492

493

494

495

496

497

498

499

500

501

502 zooxanthellae densities are needed to determine whether the metabolism of soft corals is relatively more efficient under stressful conditions compared to hard corals. Long-term monitoring data is required to determine direct causal relationships between individual water stressors and stress responses. Overall, the metabolic response of soft corals is very complex, especially in areas with simultaneous exposure to different stressors such as along the Thousand Islands. The resulting final metabolic condition in soft corals under simultaneous exposure to many stressors, as was the case in this study, depends on the interactions of the various stressors. For example, it has been shown for hard corals that chronic exposure to dissolved inorganic nitrogen can reduce calcification rates and increase the concentrations of photopigments (Marubini \& Davies, 1996) and photosynthesis rates (Fabricius, 2005). In contrast, shading due to high turbidity and sedimentation rates of $>10 \mathrm{mg} \mathrm{cm}^{-2} \mathrm{~d}^{-1}$ (Rogers, 1990) have been shown to reduce photosynthesis in hard corals, which then may lead to reduced calcification (Anthony \& Hoegh-Guldberg, 2003). Ban, Graham \& Connolly (2014) provide a comprehensive review of multiple stressor interactions and found that in most studies investigating effects of several stressors, photosynthesis was reduced. Especially for the interpretation of ETS results in this study, it is necessary to know how ETS activity can change in response to individual water parameters and how similar organisms living in symbiosis with Symbiodinium spp. may react.

The results from this study also indicate a possible different ecology of Sarcophyton spp. and Nephthea spp., since each genera showed distinct patterns in its distribution. Nephthea spp. was significantly more abundant within JB and so may have been most opportunistic and able to 
503 benefit from conditions that were not optimal for it, but far more detrimental to other species, 504 particularly stony corals. This genus may thus have had a higher tolerance towards the stressful 505 conditions in JB compared to competing hard corals. Sarcophyton spp. though, while on average 506 also being more abundant in JB, had two distinct local peaks. Under adverse conditions (JB), it 507 was most abundant at the site with the lowest inorganic nutrients (particularly $\mathrm{NH}_{3}$ and DIN) 508 within JB, Rambut. Thus, there may have been a threshold beyond which this genus could not 509 cope with the overall bad water quality (i.e. beyond which it became heavily stressed). In 510 contrast, in the Thousand Islands, where water overall was better, Sarcophyton spp. was most 511 abundant at the site with the highest concentration of $\mathrm{NH}_{3}$ and DIN, Panggang. Sarcophyton spp.

512 may have been generally less stressed in the Thousand Islands compared to JB, and thus may 513 have benefitted from the locally nutrient-enriched waters at Panggang.

514 Ecological studies from the 1980s already predicted that shifts to soft-coral dominance could be 515 expected after hard coral mass mortalities (e.g. after crown-of-thorns outbreaks) (Bradbury \& 516 Mundy, 1989). Even though alternative reef states with soft corals dominating the live benthic 517 cover are not as common and widespread as coral-macroalgae phase shifts (e.g. Hughes, 1994), 518 several studies have reported coral reefs in which the benthic community is dominated by soft 519 corals locally in the Indo-Pacific (Robinson, 1971; Nishihira \& Yamazoto, 1974; Endean, 520 Cameron \& DeVantier, 1988; Chou \& Yamazato, 1990; Fabricius, 1998) and in the western 521 Indian Ocean (Muhando \& Mohammed, 2002). According to Fabricius (2011), shifts from hard 522 to soft corals appear to be rare and restricted to productive, high-irradiance and wave-protected 523 waters with strong currents, and zooxanthellate soft corals in particular are highly affected by 524 turbidity (Fabricius \& De'ath, 2004). Neither the cover of Sarcophyton spp. nor of Nephthea spp. 525 was however significantly affected by turbidity rates within this study. Higher sedimentation 526 rates and Chl $a$ levels were positively related with higher abundances in the cover of Nephthea 527 spp. Other studies found similar trends. For example, McClanahan and Obura (1997) observed 528 that soft coral cover was higher at increased levels of sediment influence. Nonetheless, to deduce 529 whether actually shifts to soft coral dominance have occurred in Jakarta Bay, long-term 530 monitoring data is required. Cleary et al. (2008) found highly variable soft coral cover along the 531 Thousand Islands in 1995, with a cover between 0 and $6 \%$ in the bay and up to $15 \%$ at some 532 mid-and offshore sites. This indicates that soft coral cover may have increased in the bay, 533 however further surveys over several years are necessary to confirm this.

534 Other confounding stressors that may have affected metabolic condition and shifts in benthic 535 cover should be considered as well. Considering that sediments and water in JB have been 536 reported to be contaminated with heavy metals (Rees et al., 1999; Williams, Rees \& 537 Setiapermana, 2000) and organic contaminants such as the insect repellent $N, N$-diethyl- $m$ 538 toluamide (DEET) (Dsikowitzky et al., 2014), surfactants, pesticides and oil-related pollution 539 (Rinawati et al., 2012; Baum et al., 2016), a possible toxic effect with inhibition of photosystem 540 II and the mitochondrial electron transport chain could also explain the observed decreased rates 541 in ETS activity and photosynthetic yield of soft corals in the bay compared to soft corals from 542 reefs further north. A reduction in both ETS activity and photosynthetic yield rates after 
543 exposure to chemicals has been reported by several studies (e.g. Negri et al., 2005; Biscere et al., 544 2015). Heavy metals can disturb the aerobic metabolism. For example, Maes et al. (2013) 545 reported reduced ETS rates in fish after copper exposure. Similarly, herbicides and antifouling 546 agents can cause a reduction in photosynthesis in corals (see review Van Dam et al., 2011).

547 In addition, other factors such as the ability of both Sarcophyton spp. and Nephthea spp. to 548 reproduce asexually, allowing them to spread over an area in which they are already present 549 when competitors are removed (see Fabricius \& Aldersdale, 2001), as well as toxic and 550 allelopathic features (Bakus, 1981; Coll et al., 1982; Tursch \& Tursch, 1982; Sammarco et al., 551 1983; Maida, Sammarco \& Coll, 1995; Fox et al., 2003) compared to hard corals may have 552 additionally facilitated the observed soft coral dominance. For instance, Nephthea spp. produce 553 natural products that have allelopathic capacities, and the production of two of these secondary 554 metabolites has been linked to the eutrophication gradient along the Thousand Islands (Januar et al., 2011). Allelopathic features may also have affected abundances of Sarcophyton spp. At the offshore site Panggang, where relatively high nutrient concentrations and a significantly higher cover in Sarcophyton spp. was found compared to other sites from the outer Thousand Islands, the overall metabolic condition observed for Sarcophyton spp. was not significantly lower than in JB.

Another confounding factor influencing current distribution patterns of both soft coral genera

561

562

563

564

565

566

567

568

569

570

571

572

\section{3}

574

575

576

577

578

579

580

581 may be impacts of the commonly practiced blast fishing along the outer Thousand Islands in the 1980s, which caused hard coral decline (Erdman, 1998). Fox et al. (2003) reported locally high abundances of the soft coral Xenia sp. (up to 80\%) on coral rubble patches after chronic blast fishing practices in the Komodo National Park in eastern Indonesia. Xenia spp. are successful colonizers and have high fecundity and several dispersal modes (Benayahu \& Loya, 1985). Further studies should assess how both Sarcophyton spp. and Nephthea spp. are affected by the aftermath of blast fishing practices. Currently, it is not fully understood in what way shifts to soft coral dominance may be triggered by pulse disturbances (e.g. blast fishing) as top-down control and whether a loss of resilience caused by factors not considered here preceded this proximal trigger (see review by Norström et al., 2009). Further studies on how top-down control may act as a driver on soft coral dominance along the Thousand Islands are needed.

\section{Conclusions and Outlook}

Results in this study suggest that water quality, particularly eutrophication, could cause soft coral dominance in JB. Water quality has to be improved in order to prevent or reverse further phase shifts in the area. Even though this study is not able to determine direct causal relationships between individual stressors and changes in the ETS activity and photosynthetic yield of both Nephthea spp. and Sarcophyton spp., the current study indicates that the metabolic condition of both soft coral genera is affected by reduced water quality (and other anthropogenic stressors), and that ETS activity and photosynthetic yield may be useful indicators of overall metabolic condition and stress level. Future investigations should measure the responses of individual 
582 species within the two soft coral genera used in this study to test whether these species show 583 similar physiological responses. While every effort was made to sample specimens of the same 584 external appearance in each of the genera, in some cases, specimens of a similar-looking but 585 different species of the same genus may have been sampled. Therefore, physiological results 586 from this study need to be reconfirmed. Currently, there is still a lack in knowledge on 587 physiological processes and compensating mechanisms of soft corals exposed to environmental 588 stressors, however such knowledge is essential if the processes involved in shifts of benthic reef 589 communities dominated by hard corals to those dominated by soft corals is to be understood. 590 Data on respiration and photosynthesis should be combined with data on energy reserves (lipids, 591 proteins etc.) in both hard and soft corals in order to determine cellular energy allocation during stress (Novais \& Amorim, 2013). In addition, parallel to metabolic measurements, other ecological factors, such as reproductive capacity of the involved soft corals, as well as growth rates and pigment concentrations, should be determined to understand mechanisms involved in phase shifts. Management of coral reefs requires an understanding of the conditions under which phase shifts to different states occur. When considering the importance of coral reefs for the livelihoods of millions of people in developing countries, the need for more effective coral reef management is obvious.

599

600

\section{Acknowledgements}

601

602

603

604

605

606

607

\section{8}

609

610

611

612

613

614

615

616

617

618

619

620

This project was carried out within the frame of the Indonesian-German SPICE III Program (Science for the Protection of Indonesian Coastal Marine Ecosystems). We thank the following people and organizations that supported this work: Indonesian Research Center for Marine and Fisheries Products Processing and Biotechnology, Fadhilla Rahmawati and Aditya Bramandito as dive assistants, the Seribu Island National Park Officers and the officers of the P20/RCO LIPI Pari field station. Special thanks go to Jessica Knoop for help during the analysis of ETS activity.

\section{References}

Abrar M, Zamani NP. 2011. Coral recruitment, survival and growth of coral species at Pari Island, Thousand Islands, Jakarta: A case study of coral resilience. Journal of Indonesian Coral Reefs 1:7-14.

Anderson MJ. 2001. Permutation tests for univariate or multivariate analysis of variance and regression. Canadian Journal of Fisheries and Aquatic Sciences 58:626-639.

Anthony KRN, Hoegh-Guldberg O. 2003. Variation in coral photosynthesis, respiration and growth characteristics in contrasting light microhabitats: an analogue to plants in forest gaps and under storeys? Functional Ecology 17:246-259.

Arifin Z. 2004. Local millenium ecosystem assessment: Condition and trend of the Greater Jakarta Bay ecosystem. Jakarta, Republic of Indonesia: The Ministry of Environment. Bakus G. 1981. Chemical defence mechanisms on the Great Barrier Reef, Australia. Science 211:497-498. 
621

622

623

624

625

626

627

628

629

630

631

632

633

634

635

636

637

638

639

640

641

642

643

644

645

646

647

648

649

650

651

652

653

654

655

656

657

658

659

660

661

662

663

664

665

Båmstedt U. 1980. ETS activity as an estimator of respiratory rate of zooplankton populations. The significance of variations in environmental factors. Journal of Experimental Marine Biology and Ecolog 42:267-283.

Ban SS, Graham NAJ, Connolly SR. 2014. Evidence for multiple stressor interactions and effects on coral reefs. Global Change Biology 20:681-697.

Baum G, Januar HI, Ferse SCA, Kunzmann A. 2015. Local and regional impacts of pollution on coral reefs along the Thousand Islands north of the megacity Jakarta, Indonesia. PloS one 10(9): e0138271.

Baum G, Kegler P, Scholz-Böttcher BM, Alfiansah YR, Abrar M, Kunzmann A. In press. Metabolic performance of the coral reef fish Siganus guttatus exposed to combinations of water borne diesel, an anionic surfactant and elevated temperature in Indonesia. Marine Pollution Bulletin.

Bell PR, Lapointe BE, Elmetri I. 2007. Reevaluation of ENCORE: Support for the eutrophication threshold model for coral reefs. Ambio 36:416-424.

Bell PR, Elmetri I, Lapointe BE. 2014. Evidence of large-scale chronic eutrophication in the Great Barrier Reef: Quantification of chlorophyll a thresholds for sustaining coral reef communities. Ambio 43:361-376.

Bellwood DR, Hughes TP, Folke C, Nyström M. 2004. Confronting the coral reef crisis. Nature 42:827-833.

Benayahu Y. 1997. A review of three alcyonacean families (Octocorallia) from Guam. Micronesica 30:207-244.

Benayahu Y, Loya Y. 1985. Settlement and recruitment of a soft coral: Why is Xenia macrospiculata a successful colonizer? Bulletin of Marine Science 36:177-188.

Benayahu Y, Jeng MS, Perkol-Finkel S, Dai CF. 2004. Soft corals (Octocorallia: Alcyonacea) from Southern Taiwan. II. Species diversity and distributional patterns. Zoological Studies 43:548-560.

Bengen DG, Knight M, Dutton I. 2006. Managing the port of Jakarta Bay: Overcoming the legacy of 400 years of adhoc development. In: Wolanski E, ed. The Environment in Asia Pacific Harbours. Netherlands: Springer, pp. 413-431.

Berkelmans R, De'ath G, Kininmonth S, Skirving WJ. 2004. A comparison of the 1998 and 2002 coral bleaching events on the Great Barrier Reef: spatial correlation, patterns, and predictions. Coral Reefs 23:74-83.

Biscéré T, Rodolfo-Metalpa R, Lorrain A, Chauvaud L, Thébault J, Clavier J, Houlbrèque F. 2015. Responses of two scleractinian corals to cobalt pollution and ocean acidification. PLoS ONE; 10(4):e0122898.

BPS (Badan Pusat Statistik). 2012. Jumlah penduduk menurut jenis kelamin dan Rumahtangga Provinsi DKI Jakarta sampai level kelurahan (Hasil Sensus Penduduk 2000 dan 2010) (catatan: dapat menampilkan penduduk per kelompok umur, piramida penduduk dan dapat diurutkan - lihat petunjuk penggunaan). Available at http://jakarta.bps.go.id/ (accesssed on 31 May 2012).

Bradbury RH, Mundy C. 1989. Large-scale shifts in biomass of the Great Barrier Reef ecosystem. In: Sherman K, Alexander LM, eds. Biomass yields and geography of large marine ecosystems. Washington D.C.: Westview Press, p 143-167.

Bray JR, Curtis JT. 1957. An ordination of the upland forest communities of southern Wisconsin. Ecological Monographs 27:325-349. 
666

667

668

669

670

671

672

673

674

675

676

677

678

679

680

681

682

683

684

685

686

687

688

689

690

691

692

693

694

695

696

697

698

699

700

701

702

703

704

705

706

707

708

709

710

Brinkhoff T. 2011. The principal agglomerations of the world. Available: http://www.citypopulation.de (accessed 01 April 2012).

Brown EK, Cox EA, Jokiel PL, Rodgers SKu, Smith WR, Tissot BN, Coles SL, and Hultquist J. 2004. Development of Benthic Sampling Methods for the Coral Reef Assessment and Monitoring Program (CRAMP) in Hawai'i. Pacific Science 58:145-158.

Bruno JF, Selig ER. 2007. Regional decline of coral cover in the Indo-Pacific: Timing, extent, and subregional comparisons. PLoS ONE 2(8):e711.

Bruno, John F., Hugh Sweatman, William F. Precht, Elizabeth R. Selig, and Virginia GW Schutte. 2009. Assessing evidence of phase shifts from coral to macroalgal dominance on coral reefs. Ecology 6:1478-1484.

Burke L, Reytar K, Spalding MD, Perry A. 2012. Reefs at risk revisited in the Coral Triangle. Washington DC: World Resources Institute, $72 \mathrm{p}$.

Cammen LM, Corwin S, Christensen JP. 1990. Electron transport system (ETS) activity as a measure of benthic macrofaunal metabolism. Marine Ecology Progress Series 65:171182.

Cary LR. 1931. Studies on the coral reefs of Tutuila, American Samoa with special reference to the Alcyonaria. Papers of the Department of Marine Biology of the Carnegie Institute of Washington 27:53-98.

Chou LM, Yamazato K. 1990. Community structure of coral reefs within the vicinity of Motubu and Sesoko (Okinawa) and the effects of human and natural influences. Galaxea 9:9-75.

Clarke KR, Green RH. 1988. Statistical design and analysis for a" biological effects" study. Marine Ecology Progress Series 46:213-226.

Clarke KR, Ainsworth M. 1993. A method of linking multivariate community structure to environmental variables. Marine Ecology Progress Series 92:205-205.

Clarke KR, Warwick RM. 2001. Change in marine communities: An approach to statistical analysis and interpretation. Plymouth: Plymouth Marine Laboratory. PRIMER-E.

Clarke KR, Gorley RN. 2006. PRIMER v6: User Manual Tutorial. Plymouth: PRIMER-E.

Cleary DFR, Suharsono, Hoeksema BW. 2006. Coral diversity across a disturbance gradient in the Pulau Seribu reef complex off Jakarta, Indonesia. Biodiversity \& Conservation 15:3653-3674.

Cleary DFR, DeVantier L, Giyanto, Vail L, Manto P, de Voogd NJ, Rachello-Dolmen PG, Tuti Y, Budiyanto A, Wolstenholme J, Hoeksema BW. 2008. Relating variation in species composition to environmental variables: a multi-taxon study in an Indonesian coral reef complex. Aquatic Science 70:419-431.

Cleary DFR, Polónia AR, Renema W, Hoeksema BW, Wolstenholme J, Tuti Y, de Voogd N. 2014. Coral reefs next to a major conurbation: a study of temporal change (1985-2011) in coral cover and composition in the reefs of Jakarta, Indonesia. Marine Ecology Progress Series 501:89-98.

Coll J, Bowden BF, Tapiolasand DM, Dunlap WC. 1982. In situ isolation of allelo chemicals released from soft corals Coelenterata: Octocorallia): a totally submersible sampling apparatus. Journal of Experimental Marine Biology and Ecology 60:293-299.

De'ath G, Fabricius K. 2010. Water quality as a regional driver of coral biodiversity and macroalgae on the Great Barrier Reef. Ecological Applications 20:840-850.

DeVantier L, Suharsono, Budiyanto A, Tuti Y, Imanto P, Ledesma R. 1998. Status of coral communities of Pulau Seribu (Indonesia). In: Soemodihardjo S, ed. Contending with 
711

712

713

714

715

716

717

718

719

720

721

722

723

724

725

726

727

728

729

730

731

732

733

734

735

736

737

738

739

740

741

742

743

744

745

746

747

748

749

750

751

752

753

754

755

Global Change 10. Proceedings of coral reef evaluation workshop, Pulau Seribu, Jakarta, Indonesia, 1995. UNESCO, Jakarta, pp. 1-24.

Dinesen ZD. 1983. Patterns in the distribution of soft corals across the central Great Barrier Reef. Coral Reefs 1:229-236.

Djohani RH. 1994. Patterns of spatial distribution, diversity and cover of corals in Pulau Seribu National Park: implications for the design of core coral sanctuaries. Proceedings of IOCWESTPAC 3rd International Science Symposium. Bali, Indonesia. pp. 265-279.

Done TJ. 1982. Patterns in the distribution of coral communities across the central Great Barrier Reef. Coral Reefs 1:95-107.

Dsikowitzky L, Heruwati E, Ariyani F, Irianto HE, Schwarzbauer J. 2014. Exceptionally high concentrations of the insect repellent N, N-diethyl-m-toluamide (DEET) in surface waters from Jakarta, Indonesia. Environmental Chemistry Letters 12:407-411.

Endean R, Cameron AM, Devantier LM. 1988. Acanthaster planci predation on massive corals: the myth of rapid recovery of devastated reefs. Proceedings of the 6th International Coral Reef Symposium. 2:143-148.

English SS, Wilkinson CC, Baker VV. 1994. Survey manual for tropical marine resources. Australian Institute of Marine Science (AIMS).

Erdman M. 1998. Destructive fishing practice in Kepulauan Seribu Archipelago. Proceedings of the Coral Reef Evaluation Workshop, Kepulauan Seribu. Jakarta. pp. 84-89.

Fabricius KE. 1998. Reef invasion by soft corals: which taxa and which habitats? In: Greenwood JG, Hall NJ (eds.) Proceedings of the Australian Coral Reef Society 75th Anniversary Conference, Heron Island, Great Barrier Reef, School of Marine Science, University of Queensland, Brisbane. p 77-90.

Fabricius KE. 2005. Effects of terrestrial runoff on the ecology of corals and coral reefs: review and synthesis. Marine Pollution Bulletin 50:125-146.

Fabricius KE. 2011. Factors determining the resilience of coral reefs to eutrophication: a review and conceptual model. In: Coral Reefs: An ecosystem in transition. Netherlands: Springer, pp. 493-505.

Fabricius KK, Alderslade PP. 2001. Soft corals and sea fans: a comprehensive guide to the tropical shallow water genera of the central-west Pacific, the Indian Ocean and the Red Sea. Australian Institute of Marine Science (AIMS).

Fabricius KE, Cooper TF, Humphrey C, Uthicke S, De'ath G, Davidson J,LeGrand H, Thompson A, Schaffelke B. 2012. A bioindicator system for water quality on inshore coral reefs of the Great Barrier Reef. Marine Pollution Bulletin 65:320-332.

Fabricius KE, De'Ath G. 2004. Identifying ecological change and its causes: a case study on coral reefs. Ecological Applications 14:1448-1465.

Fabricius KE, Dommisse M. 2000. Depletion of suspended particulate matter over coastal reef communities dominated by zooxanthellate soft corals. Marine Ecology Progress Series 196:157-167.

Fanslow DL, Nalepa TF, Johengen TH. 2001. Seasonal changes in the respiratory electron transport system (ETS) and respiration of the zebra mussel, Dreissena polymorpha in Saginaw Bay, Lake Huron. Hydrobiologia 448:61-70.

Folke C, Carpenter S, Walker B, Scheffer M, Elmqvist T, Gunderson L, Holling CS. 2004. Regime shifts, resilience, and biodiversity in ecosystem management. Annual Review of Ecology, Evolution, and Systematics 35:557-581. 
756

757

758

759

760

761

762

763

764

765

766

767

768

769

770

771

772

773

774

775

776

777

778

779

780

781

782

783

784

785

786

787

788

789

790

791

792

793

794

795

796

797

798

799

800

801

Fox HE, Pet JS, Dahuri R, Caldwell RL. 2003. Recovery in rubble fields: long-term impacts of blast fishing. Marine Pollution Bulletin 46:1024-1031.

GESAMP. 2001. Protecting the oceans from land-based activities. Land-based sources and activities affecting the quality and uses of the marine, coastal and associated freshwater environment. Nairobi: United Nations Environment Program, 71.

Gomez ED, Yap HT. 1988. Monitoring reef condition. Coral reef management handbook UNESCO regional office for science and technology for southeast Asia (ROSTSEA). Jakarta, p. 171-178.

Gómez M, Torres S, Hernández-León S. 1996. Modification of the electron transport system (ETS) method for routine measurements of respiratory rates of zooplankton. South African Journal of Marine Science 17:15-20.

Holmes KE, Edinger EN, Hariyadi, Limmon GV, Risk MJ. 2000. Bioerosion of live massive corals and branching coral rubble on Indonesian coral reefs. Mar Pollut Bull 40: 606617.

Hughes TP. 1994. Catastrophes, phase-shifts, and large-scale degradation of a Caribbean coral reef. Science 265:1547-1551.

Hughes TP, Rodrigues MJ, Bellwood DR, Ceccarelli D, Hoegh-Guldberg O, McCook L,Moltschaniwskyi N, Pratchett MS, Steneck RS, Willis B. 2007. Phase shifts, herbivory, and the resilience of coral reefs to climate change. Current Biology 17:360-365.

Hughes TP, Graham NAJ, Jackson JBC, Mumby PJ, Steneck RS. 2010. Rising to the challenge of sustaining coral reef resilience. Trends in Ecology \& Evolution 25:633-642.

Ikeda T. 1989. Estimated respiration rate of myctophid fish from the enzyme activity of the electron-transport-system. Journal of the Oceanographical Society of Japan 45: 167-173.

Januar HI, Hendrarto B, Chasanah E, Wright AD. 2011. Nephthea sp.: Correlation between natural products production and pressure from local environmental stressors. Journal of Marine Science Research Development S8:001.

Jones RJ, Kildea T, Hoegh-Guldberg O. 1999. PAM Chlorophyll fluorometry: A new in situ technique for stress assessment in scleractinian corals, used to examine the effects of cyanide from cyanide fishing. Marine Pollution Bulletin 38:864-874.

Kohler KE, Gill SM. 2006. Coral Point Count with Excel extensions (CPCe): A Visual Basic program for the determination of coral and substrate coverage using random point count methodology. Computer \& Geosciences 32:1259-1269.

Ladwig N, Hesse K-J, Van der Wulp SA, Damar A, Koch D. In press. Pressure on oxygen levels of Jakarta Bay. Marine Pollution Bulletin Special Issue Jakarta Bay Ecosystem.

Lannig G, Eckerle LG, Serendero I, Sartoris FBJ, Fischer T, Knust R, Johansen T, Pörtner HBO. 2003. Temperature adaptation in eurythermal cod (Gadus morhua): a comparison of mitochondrial enzyme capacities in boreal and arctic populations. Marine Biology 142:589-599.

Lesser MP. 2013. Using energetic budgets to assess the effects of environmental stress on corals: are we measuring the right things? Coral Reefs 32:25-33.

Loya Y. 2004. The coral reefs of Eilat- past, present and future: three decades of coral community structure studies. In: Rosenberg E, Loya Y, eds. Coral Reef Health and Disease. Springer, Berlin, p. 396.

Madduppa HH, Ferse SC, Aktani U, Palm HW. 2012. Seasonal trends and fish-habitat associations around Pari Island, Indonesia: setting a baseline for environmental monitoring. Environmental Biology of Fishes 95:383-398. 
802

803

804

805

806

807

808

809

810

811

812

813

814

815

816

817

818

819

820

821

822

823

824

825

826

827

828

829

830

831

832

833

834

835

836

837

838

839

840

841

842

843

844

845

Maes V, Vettier A, Jaffal A, Dedourge-Geffard O, Delahaut L, Geffard A, Betoulle S, David E. 2013. Energy metabolism and pesticides: biochemical and molecular responses to copper in roach Rutilus rutilus. Journal of Xenobiotics 3:7.

Maida M, Sammarco PW, Coll JC. 1995. Effects of soft corals on scleractinian coral recruitment: Directional allelopathy and inhibition of settlement. Marine Ecology Progress Series 121:191-202.

Marubini F. 1996. The physiological response of hermatypic corals to nutrient enrichment. Faculty of Science. University of Glasgow, Glasgow, p. 192.

Marubini F, Davies PS. 1996. Nitrate increases zooxanthellae population density and reduces skeletogenesis in corals. Marine Biology 127:319-328.

McClanahan TR, Obura D. 1997. Sedimentation effects on shallow coral communities in Kenya. Journal of Experimental Marine Biology and Ecology 209:103-122.

Moll H, Suharsono. 1986 Distribution, diversity and abundance of reef corals in Jakarta Bay and Kepulauan Seribu. In: Brown BE, ed. Human induced damage to coral reefs: Results of a Regional UNESCO (COMAR) Workshop with Advanced Training, UNESCO Reports in Marine Science, 40. Diponegoro University, Jepara and National Institute of Oceanology, Jakarta, Indonesia.

Muhando CA, Mohammed M. 2002. Coral reef benthos and fisheries in Tanzania before and after the 1998 bleaching and mortality event. West Indian Ocean Journal of Marine Science 1:43-52. Munday PL. 2004. Habitat loss, resource specialization, and extinction on coral reefs. Global Change Biology 10:1642-1647.

Muscatine L, Falkowski PG, Porter JW, Dubinsky Z. 1984. Fate of photosynthetically fixed carbon in light- and shade adapted colonies of the symbiotic coral Stylophora pistillata. Proceedings of the Royal Society of London B: Biological Sciences 222:181-202.

Nahrgang J, Brooks SJ, Evenset A, Camus L, Jonsson M, Smith TJ, Lukina J, Frantzen M, Giarratano E, Renaud PE. 2013. Seasonal variation in biomarkers in blue mussel (Mytilus edulis), Icelandic scallop (Chlamys islandica) and Atlantic cod (Gadus morhua) Implications for environmental monitoring in the Barents Sea. Aquatic Toxicology 127:21-35.

Negri A, Vollhardt C, Humphrey C, Heyward A, Jones R, Eaglesham G, Fabricius K. 2005. Effects of the herbicide diuron on the early life history stages of coral. Marine Pollution Bulletin 51:370-383.

Nishihira M, Yamazoto K. 1974. Human interference with the coral reef community and Acanthaster infestation of Okinawa. Proceedings of the Second International Symposium on Coral Reefs. p. 577-590.

Norström AV, Nyström M, Lokrantz J, Folke C. 2009. Alternative states on coral reefs: beyond coral-macroalgal phase shifts. Marine Ecology Progress Series 376:295-306.

Novais SC, Amorim MJ. 2013. Changes in cellular energy allocation in Enchytraeus albidus when exposed to dimethoate, atrazine, and carbendazim. Environmental Toxicology and Chemistry 32:2800-2807.

Nyström M, Folke C, Moberg F. 2000. Coral reef disturbance and resilience in a humandominated environment. Trends in Ecology and Evolution 15:413-417.

Owens TG, King FD. 1975. The measurement of respiratory electron transport system activity in marine zooplankton. Marine Biology 30:27-36. 
846

847

848

849

850

851

852

853

854

855

856

857

858

859

860

861

862

863

864

865

866

867

868

869

870

871

872

873

874

875

876

877

878

879

880

881

882

883

884

885

886

887

888

889

890

891

Rachello-Dolmen PG, Cleary DFR. 2007. Relating coral species traits to environmental conditions in the Jakarta Bay/Pulau Seribu reef system, Indonesia. Estuarine, Coastal and Shelf Science 73:816-826.

Rasher DB, Engel S, Bonito V, Fraser GJ, Montoya JP, Hay ME. 2012. Effects of herbivory, nutrients, and reef protection on algal proliferation and coral growth on a tropical reef. Oecologia 169:187-198.

Rees JG, Setiapermana D, Sharp VA, Weeks JM, Williams TM. 1999. Evaluation of the impacts of land-based contaminants on the benthic faunas of Jakarta Bay, Indonesia. Oceanologica Acta 22:627-640.

Rinawati, Koike T, Koike H, Kurumisawa R, Ito M, Sakurai S, Togo A, Saha M, Arifin Z, Takada H. 2012. Distribution, source identification, and historical trends of organic micropollutants in coastal sediment in Jakarta Bay, Indonesia. Journal of Hazardous Materials 217:208-216.

Robinson DE. 1971. Observations on Fijian coral reefs and the crown-of-thorns starfish. Journal of the Royal Society of New Zealand 1:99-112.

Rodolfo-Metalpa R, Huot Y, Ferrier-Pagès C. 2008. Photosynthetic response of the Mediterranean zooxanthellate coral Cladocora caespitosa to different light and temperature conditions. Journal of Experimental Biology 211:1579-1586.

Rogers CS. 1990. Responses of coral reefs and reef organisms to sedimentation. Marine Ecology Progress Series 62:185-202.

Sammarco PW, Coli JC, La Barre S, Willis B. 1983. Competitive strategies of soft corals (Coelenterata: Octocorallia): allelopathic effects on selected scleractinian corals. Coral Reefs I:173-178.

Selig ER, Harvell CD, Bruno JF, Willis BL, Page CA, Casey KS, Sweatman H. 2006. Analyzing the relationship between ocean temperature anomalies and coral disease outbreaks at broad spatial scales. In: Phinney J, Hoegh-Guldberg O, Kleypas J, Skirving W, Strong A, eds. Coral reefs and climate change: Science and management. Washington DC: American Geophysical Union, pp. 111-128.

Stanley Jr GD. 2003. The evolution of modern corals and their early history. Earth-Science Reviews 60: 195-225.

Stimson J, Larned ST. 2000. Nitrogen efflux from sediments of a subtropical bay and the potential contribution to macroalgal nutrient requirements. Journal of Experimental Marine Biology and Ecology 252:159-180.

Storlazzi CD, Field ME, Bothner MH. 2011. The use (and misuse) of sediment traps in coral reef environments: theory, observations, and suggested protocols. Coral Reefs 30:23-38.

Szmant AM. 2002. Nutrient enrichment on coral reefs: is it a major cause of coral reef decline? Estuaries 25:743-766.

Tursch B, Tursch A. 1982. The soft coral communities on a sheltered reef quadrat at Laing Island (Papua New Guinea). Marine Biology 68:321-332.

Ulstrup KE, Kühl M, van Oppen MJH, Cooper TF, Ralph PJ. 2011. Variation in photosynthesis and respiration in geographically distinct populations of two reef-building coral species. Aquatic Biology 12:241-248.

UN. 2014. World Urbanization Prospects, the 2014 Revision. Highlights. United Nations, New York, $32 \mathrm{pp}$.

van Dam JW, Negri AP, Uthicke S, Mueller JF. 2011. Chemical pollution on coral reefs: exposure and ecological effects. Ecological Impact of Toxic Chemicals 187-211. 
892

893

894

895

896

897

898

899

900

901

902

903

904

905

906

907

908

909

910

911

912

913

van der Meij SET, Suharsono, and Hoeksema BW. 2010. Long-term changes in coral assemblages under natural and anthropogenic stress in Jakarta Bay (1920-2005). Marine Pollution Bulletin 60:1442-1454.

Van der Wulp SA, Hesse KJ, Ladwig N, Damar A. In press. Numerical simulations of River discharges, Nutrient flux and nutrient dispersal in Jakarta Bay, Indonesia. Marine Pollution Bulletin Special Issue Jakarta Bay Ecosystem.

Verstappen HT. 1953. Djakarta Bay-a geomorphological study on shoreline development. Doctoral dissertation. University of Utrecht. pp. 1-101.

Walz H. 1998. Underwater fluorometer diving-PAM, submersible photosynthesis yield analyzer Handbook of operation. Effeltrich: Heinz Walz GmbH.

Ward-Paige CA, Risk MJ, Sherwood OA, Jaap WC. 2005. Clionid sponge surveys on the Florida Reef Tract suggest land-based nutrient inputs. Marine Pollution Bulletin 51:570-579.

Williams TM, Rees JG, Setiapermana D. 2000. Metals and trace organic compounds in sediments and waters of Jakarta Bay and the Pulau Seribu Complex, Indonesia. Marine Pollution Bulletin 40:277-285.

Zaneveld JS, Verstappen HT. 1952. A recent investigation about the geomorphology and the flora of some coral islands in the Bay of Djakarta. Journal of Scientific Research 3:5868. 


\section{Tables}

915

916 Table 1. Description of sampling sites (linear distance refers to distance from each site to the 917 harbor Muara Angke in Jakarta).

\begin{tabular}{l|c|c|c|c} 
Site & $\begin{array}{c}\text { Site } \\
\text { abbrev. }\end{array}$ & $\begin{array}{c}\text { Longitude } \\
{[\mathbf{E}]}\end{array}$ & $\begin{array}{c}\text { Latitude } \\
{[\mathbf{S}]}\end{array}$ & $\begin{array}{c}\text { Linear distance to Jakarta } \\
{[\mathbf{k m}]}\end{array}$ \\
\hline Ayer Besar & $\mathrm{AB}$ & $106^{\circ} 42.242$ & $05^{\circ} 58.399$ & 11.3 \\
Untung Jawa & $\mathrm{UJ}$ & $106^{\circ} 46.911$ & $05^{\circ} 58.399$ & 16.4 \\
Rambut & $\mathrm{R}$ & $106^{\circ} 41.597$ & $05^{\circ} 58.202$ & 17.3 \\
Pari South & PS & $106^{\circ} 36.963$ & $05^{\circ} 52.094$ & 31.4 \\
Pari North & PN & $106^{\circ} 37.440$ & $05^{\circ} 51.001$ & 32.6 \\
Gosong Panggang & P & $106^{\circ} 35.355$ & $05^{\circ} 44.664$ & 45.7 \\
Gosong Conkak & $\mathrm{C}$ & 10635.274 & $05^{\circ} 42.303$ & 49.5 \\
Kayu Angin Bira & $\mathrm{B}$ & $106^{\circ} 34.162$ & $05^{\circ} 36.405$ & 59.8
\end{tabular}

918

919

920

921

922

923

924

925

926

927

928

929

930

931

932

933

934 
936 Table 2. Mean cover $( \pm$ SD) at each site $(n=3$ transects per site) for hard and soft corals, the 937 two soft coral genera Sarcopyhton spp. and Nephthea spp., macroalgae, other live as well as total 938 coral cover for sites along the Thousand Islands. Study sites: $\mathrm{AB}=$ Ayer Besar, UJ = Untung 939 Jawa, $\mathrm{R}=$ Rambut, $\mathrm{PS}=$ Pari South, $\mathrm{PN}=$ Pari North, $\mathrm{P}=$ Panggang, $\mathrm{C}=$ Congkak, $\mathrm{B}=\mathrm{Bira}$.

\begin{tabular}{c|c|l|c|c|c|c|c|c}
\multicolumn{2}{c}{ Site } & $\begin{array}{l}\text { Hard } \\
\text { coral } \\
\text { [\% } \\
\text { cover] }\end{array}$ & $\begin{array}{l}\text { Macroalga } \\
\text { e [\% cover] }\end{array}$ & $\begin{array}{l}\text { Soft coral } \\
{[\% \text { cover] }]}\end{array}$ & $\begin{array}{l}\text { Nephthea spp. } \\
{[\% \text { cover] }}\end{array}$ & $\begin{array}{l}\text { Sarcophyton } \\
\text { spp. [\% } \\
\text { cover] }\end{array}$ & $\begin{array}{l}\text { Total } \\
\text { coral } \\
{[\%} \\
\text { cover }]\end{array}$ & $\begin{array}{l}\text { Other } \\
\text { live [\% } \\
\text { cover] }\end{array}$ \\
\hline \multirow{3}{*}{ Jakarta } & AB & $5 \pm 3$ & $8 \pm 2$ & $9 \pm 5$ & $4 \pm 2$ & $5 \pm 4$ & $13 \pm 2$ & $4 \pm 2$ \\
Bay (JB) & UJ & $1 \pm 1$ & $10 \pm 1$ & $8 \pm 3$ & $6 \pm 2$ & $2 \pm 1$ & $9 \pm 3$ & $3 \pm 1$ \\
& R & $2 \pm 1$ & $9 \pm 3$ & $22 \pm 9$ & $2 \pm 2$ & $14 \pm 6$ & $23 \pm 8$ & $2 \pm 2$ \\
& Mean & $2 \pm 2$ & $9 \pm 2$ & $13 \pm 6$ & $4 \pm 2$ & $7 \pm 4$ & $15 \pm 4$ & $3 \pm 2$ \\
\hline & PS & $28 \pm 5$ & $2 \pm 0$ & $6 \pm 4$ & $0 \pm 0$ & $0 \pm 0$ & $34 \pm 2$ & $2 \pm 1$ \\
Outer & PN & $47 \pm 11$ & $2 \pm 1$ & $2 \pm 3$ & $0 \pm 0$ & $0 \pm 0$ & $49 \pm 9$ & $1 \pm 1$ \\
Islands & P & $18 \pm 7$ & $7 \pm 5$ & $22 \pm 10$ & $0 \pm 0$ & $20 \pm 8$ & $40 \pm$ & $2 \pm 1$ \\
& C & $30 \pm 3$ & $3 \pm 1$ & $4 \pm 2$ & $0 \pm 0$ & $3 \pm 2$ & $35 \pm 2$ & $6 \pm 2$ \\
& B & $19 \pm 4$ & $1 \pm 0$ & $0 \pm 0$ & $0 \pm 0$ & $0 \pm 0$ & $19 \pm 4$ & $7 \pm 1$ \\
& Mean & $28 \pm 6$ & $3 \pm 1$ & $7 \pm 8$ & $0 \pm 0$ & $5 \pm 2$ & $35 \pm 6$ & $4 \pm 1$
\end{tabular}


Table 3. Univariate analyses (linear regression) to test for correlations between the metabolic condition indicated by photosynthetic yield $\left(\mathrm{F}_{\mathrm{v}} / \mathrm{F}_{\mathrm{m}}\right)$ and electron transport system (ETS) activity of the two soft coral genera Sarcophyton spp. and Nephthea spp. as well as the benthic cover with the distance to Jakarta, water factors and the cover of both soft coral genera. $p$-values are given. * refers to 2 linear segments (i.e. one breaking point).

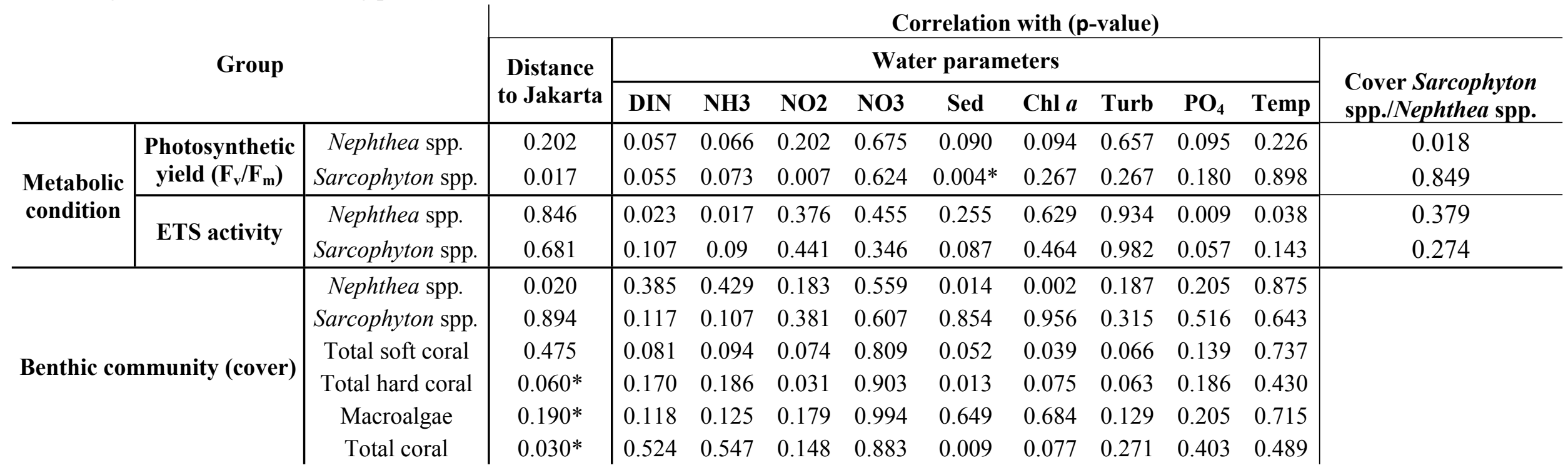


Table 4. Water quality. Data for sites in Jakarta Bay (JB) and outer Thousand Islands (see Baum et al. (2015) for details): Mean values $( \pm \mathrm{SD})$ for the factors temperature $\left[{ }^{\circ} \mathrm{C}\right], \mathrm{pH}$, salinity [PSU], DO $[\mathrm{mg} / \mathrm{L}]$, turbidity $[\mathrm{NTU}]$, sedimentation, the inorganic nutrients $[\mu \mathrm{M} / \mathrm{L}] \mathrm{PO}_{4}, \mathrm{NO}_{3}, \mathrm{NO}_{2}, \mathrm{NH}_{4}$ and $\mathrm{Chl} a[\mu \mathrm{g} / \mathrm{L}]$ at each site. The \% difference between JB and outer Thousand Islands as well as $p$ values for differences between sites along the whole island chain (one-way ANOVA) and for linear regression analysis with distance to Jakarta are given for each factor. Study sites: $\mathrm{AB}=$ Ayer Besar, UJ = Untung Jawa, R = Rambut, PS = Pari South, PN = Pari North, $\mathrm{P}=$ Panggang, $\mathrm{C}=$ Congkak, $\mathrm{B}=$ Bira.

\begin{tabular}{|c|c|c|c|c|c|c|c|c|c|c|c|c|c|}
\hline Are & & $\begin{array}{c}\text { Tubidity } \\
\text { [NTU] }\end{array}$ & Chl $a[\mu \mathrm{g} / \mathrm{L}]$ & $\begin{array}{c}\mathrm{PO}_{4} \\
{[\mu \mathrm{M} / \mathrm{L}]} \\
\end{array}$ & $\mathbf{N H}_{3}[\mu \mathbf{M} / \mathbf{L}]$ & $\begin{array}{c}\mathrm{NO}_{2} \\
{[\mu \mathrm{M} / \mathrm{L}]}\end{array}$ & $\begin{array}{c}\mathrm{NO}_{3} \\
{[\mu \mathrm{M} / \mathrm{L}]} \\
\end{array}$ & $\begin{array}{c}\text { Sedimentation rate } \\
{\left[\mathbf{g ~ m}^{-2} \mathbf{d}^{-1}\right]}\end{array}$ & $\operatorname{DIN}[\boldsymbol{\mu M} / \mathbf{L}]$ & $\begin{array}{c}\text { Temperature } \\
{\left[{ }^{\circ} \mathbf{C}\right]} \\
\end{array}$ & pH & $\begin{array}{c}\text { Salinity } \\
\text { [PSU] }\end{array}$ & DO \\
\hline \multirow{4}{*}{$\begin{array}{l}\text { Jakarta Bay } \\
\text { (JB) }\end{array}$} & Mean & $1.49 \pm 0.25$ & $9.48 \pm 1.27$ & $2.36 \pm 1.23$ & $6.65 \pm 1.32$ & $0.42 \pm 0.10$ & $0.57 \pm 1.16$ & $30.39 \pm 4.96$ & $7.64 \pm 0.87$ & $30.47 \pm 0.03$ & $8.19 \pm 0.01$ & $32.41 \pm 0.04$ & $6.78 \pm 0.23$ \\
\hline & $\mathbf{A B}$ & $0.73 \pm 0.18$ & $4.86 \pm 0.57$ & $4.09 \pm 2.79$ & $11.64 \pm 2.36$ & $0.5 \pm 0.09$ & $0.55 \pm 0.10$ & $31.02 \pm 5.89$ & $12.69 \pm 0.40$ & $30.48 \pm 0.03$ & $8.33 \pm 0.00$ & $32.24 \pm 0.05$ & $8.39 \pm 0.17$ \\
\hline & UJ & $1.32 \pm 0.26$ & $15.77 \pm 1.96$ & $1.68 \pm 0.73$ & $4.62 \pm 0.94$ & $0.23 \pm 0.11$ & $0.67 \pm 0.15$ & $30.16 \pm 4.72$ & $5.52 \pm 1.22$ & $30.24 \pm 0.05$ & $8.09 \pm 0.01$ & $32.62 \pm 0.04$ & $5.54 \pm 0.26$ \\
\hline & $\mathbf{R}$ & $2.4 \pm 0.27$ & $7.81 \pm 1.30$ & $1.31 \pm 0.18$ & $3.7 \pm 0.65$ & $0.53 \pm 0.10$ & $0.48 \pm 0.24$ & $30 \pm 4.28$ & $4.71 \pm 1.00$ & $30.68 \pm 0.00$ & $8.16 \pm 0.00$ & $32.36 \pm 0.03$ & $6.41 \pm 0.26$ \\
\hline \multirow{6}{*}{$\begin{array}{l}\text { Outer } \\
\text { Thousand } \\
\text { Islands }\end{array}$} & Mean & $0.49 \pm 0.20$ & $1.76 \pm 0.30$ & $1.41 \pm 0.35$ & $3.64 \pm 0.62$ & $0.14 \pm 0.04$ & $0.48 \pm 0.16$ & $16.18 \pm 4.96$ & $4.25 \pm 0.87$ & $30.41 \pm 0.02$ & $8.15 \pm 0.01$ & $32.77 \pm 0.04$ & $6.64 \pm 0.07$ \\
\hline & PS & $0.42 \pm 0.27$ & $1.48 \pm 0.15$ & $0.51 \pm 0.08$ & $2.82 \pm 0.88$ & $0.27 \pm 0.04$ & $1.02 \pm 0.13$ & $10.54 \pm 2.60$ & $4.11 \pm 1.05$ & $30.35 \pm 0.03$ & $8.14 \pm 0.00$ & $32.63 \pm 0.03$ & $6.59 \pm 0.10$ \\
\hline & PN & $0.42 \pm 0.14$ & $2.84 \pm 0.20$ & $0.11 \pm 0.02$ & $0.46 \pm 0.28$ & $0.01 \pm 0.01$ & $0.65 \pm 0.17$ & $13.91 \pm 3.18$ & $1.11 \pm 0.46$ & $30.83 \pm 0.00$ & $8.18 \pm 0.00$ & $32.74 \pm 0.03$ & $6.50 \pm 0.03$ \\
\hline & $\mathbf{P}$ & $0.54 \pm 0.18$ & $1.78 \pm 0.41$ & $4.35 \pm 1.22$ & $11.41 \pm 0.73$ & $0.16 \pm 0.10$ & $0.39 \pm 0.10$ & $14.41 \pm 1.06$ & $11.96 \pm 0.94$ & $30.14 \pm 0.03$ & $8.14 \pm 0.00$ & $32.95 \pm 0.03$ & $6.21 \pm 0.07$ \\
\hline & C & $0.52 \pm 0.24$ & $0.89 \pm 0.05$ & $0.05 \pm 0.05$ & $2.03 \pm 0.68$ & $0.14 \pm 0.02$ & $0.16 \pm 0.00$ & $20.37 \pm 3.50$ & $2.33 \pm 0.70$ & $30.36 \pm 0.03$ & $8.18 \pm 0.00$ & $32.78 \pm 0.03$ & $6.58 \pm 0.06$ \\
\hline & B & $0.54 \pm 0.17$ & $1.84 \pm 0.70$ & $2.04 \pm 0.40$ & $1.48 \pm 0.54$ & $0.1 \pm 0.02$ & $0.16 \pm 0.18$ & $21.65 \pm 4.67$ & $1.74 \pm 0.76$ & $30.34 \pm 0.02$ & $8.13 \pm 0.00$ & $32.74 \pm 0.05$ & $6.47 \pm 0.10$ \\
\hline \multicolumn{2}{|c|}{$\begin{array}{c}\% \text { difference JB and } \\
\text { Outer Thousand Islands }\end{array}$} & 67 & 81.41 & 40.19 & 45.28 & 67.58 & 16.38 & 46.78 & 44.35 & 0.2 & 0.47 & 1.12 & 2.05 \\
\hline \multicolumn{2}{|c|}{$\begin{array}{c}\text { One-Way ANOVA (p- } \\
\text { value) }\end{array}$} & 0.005 & 0.003 & $<0.001$ & $<0.001$ & $<0.001$ & $<0.001$ & $<0.001$ & $<0.001$ & 0.114 & 0.083 & 0.007 & 0.106 \\
\hline \multicolumn{2}{|c|}{$\begin{array}{l}\text { Correlation with distance } \\
\text { to Jakarta ( } p \text {-value) }\end{array}$} & 0.15 & 0.07 & 0.7 & 0.47 & 0.42 & 0.03 & $0.01 *$ & 0.15 & 0.44 & 0.37 & 0.02 & 0.56 \\
\hline
\end{tabular}


961 Table 5. Correlation between the metabolic condition indicated by photosynthetic yield $\left(\mathrm{F}_{\mathrm{v}} / \mathrm{F}_{\mathrm{m}}\right)$ 962 and electron transport system (ETS) activity of the two soft coral genera Sarcophyton spp. and 963 Nephthea spp., respectively, and the water quality as well as live benthic cover. Data are based 964 on the test BioEnv (correlation factors are shown).

\begin{tabular}{|c|c|c|c|c|c|}
\hline & \multirow{3}{*}{ Group } & \multicolumn{4}{|c|}{ Correlation with } \\
\hline & & \multicolumn{2}{|c|}{$\begin{array}{c}\text { Water } \\
\text { parameters }\end{array}$} & \multicolumn{2}{|c|}{ Live benthic cover } \\
\hline & & Corr & Factor & Corr & Factor \\
\hline \multirow{5}{*}{$\begin{array}{l}\text { Metabolic } \\
\text { condition }\end{array}$} & & & $\mathrm{PO}_{4}$ & & $\begin{array}{c}\text { Sarcophyton } \\
\text { spp. }\end{array}$ \\
\hline & Nephthea spp. & 0.79 & $\mathrm{NH}_{3}$ & 0.12 & Macroalgae \\
\hline & & & Temp & & Hard coral \\
\hline & & & $\mathrm{DO}$ & \multirow{7}{*}{0.06} & Macroalgae \\
\hline & Sarcophyton spp. & 0.68 & $\begin{array}{c}\mathrm{pH} \\
\text { Temp }\end{array}$ & & \multirow[t]{6}{*}{$\begin{array}{c}\text { Nephthea spp. } \\
\text { Hard coral }\end{array}$} \\
\hline \multirow{5}{*}{$\begin{array}{c}\text { Benthic } \\
\text { community }\end{array}$} & & & $\mathrm{NH}_{3}$ & & \\
\hline & Overall & 0.71 & $\mathrm{NO}_{2}$ & & \\
\hline & & & Turb & & \\
\hline & Cover of Nephthea & & Sed & & \\
\hline & $\begin{array}{c}\text { spp. and Sarcophyton } \\
\text { spp. }\end{array}$ & 0.39 & $\mathrm{NH}_{3}$ & & \\
\hline
\end{tabular}

966

967

968

969

970

971

972

973

974

975

976

977 


\section{Figures}

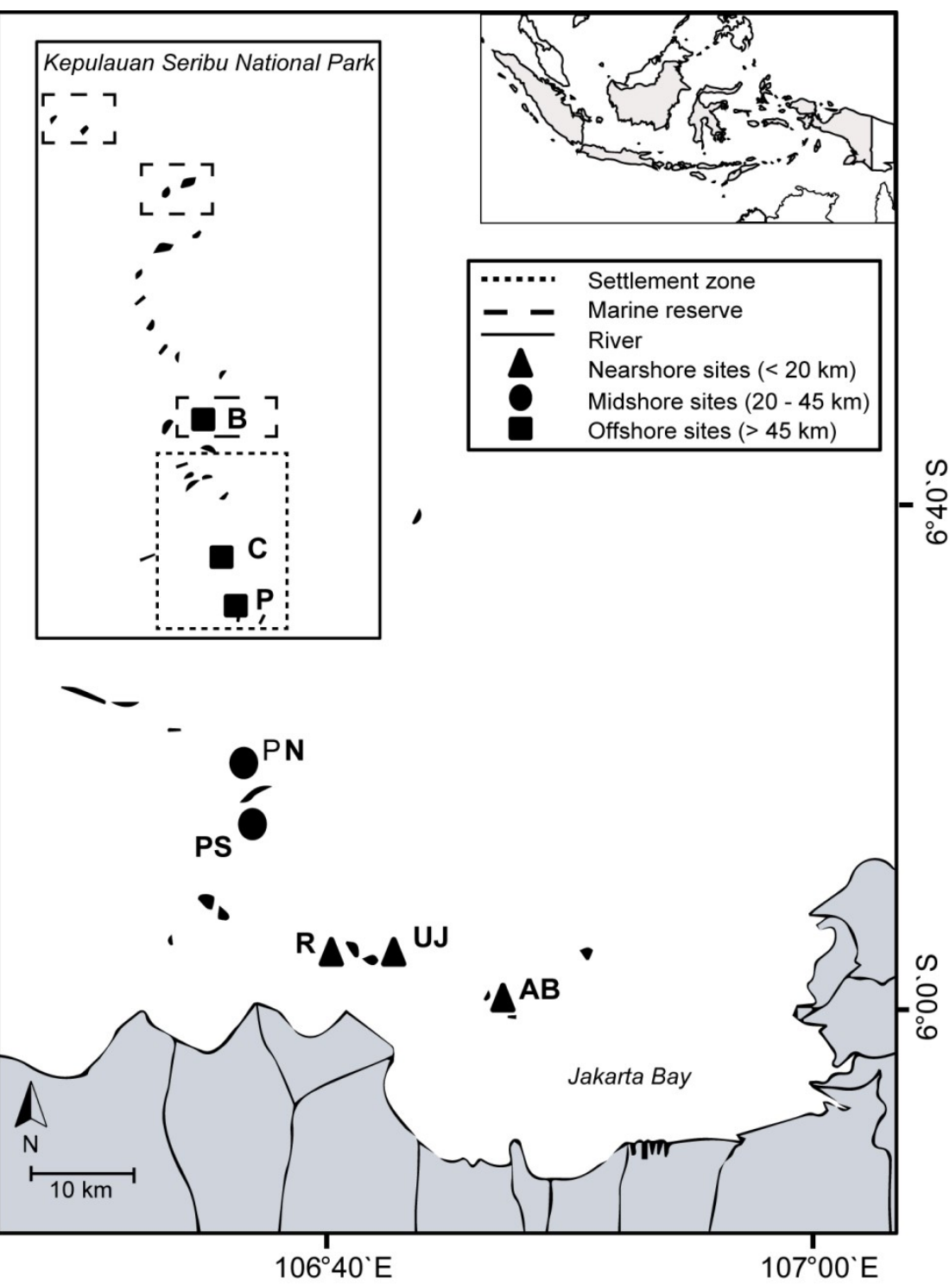

Fig. 1. Study area including boundaries of the Thousand Islands Marine National Park and study sites from nearshore reefs (within Jakarta Bay), as well as from the outer Thousand Islands (midand offshore): $\mathrm{AB}=$ Ayer Besar, UJ = Untung Jawa, $\mathrm{R}=$ Rambut, PS = Pari South, PN = Pari North, $\mathrm{P}=$ Panggang, $\mathrm{C}=$ Congkak, $\mathrm{B}=$ Bira. 

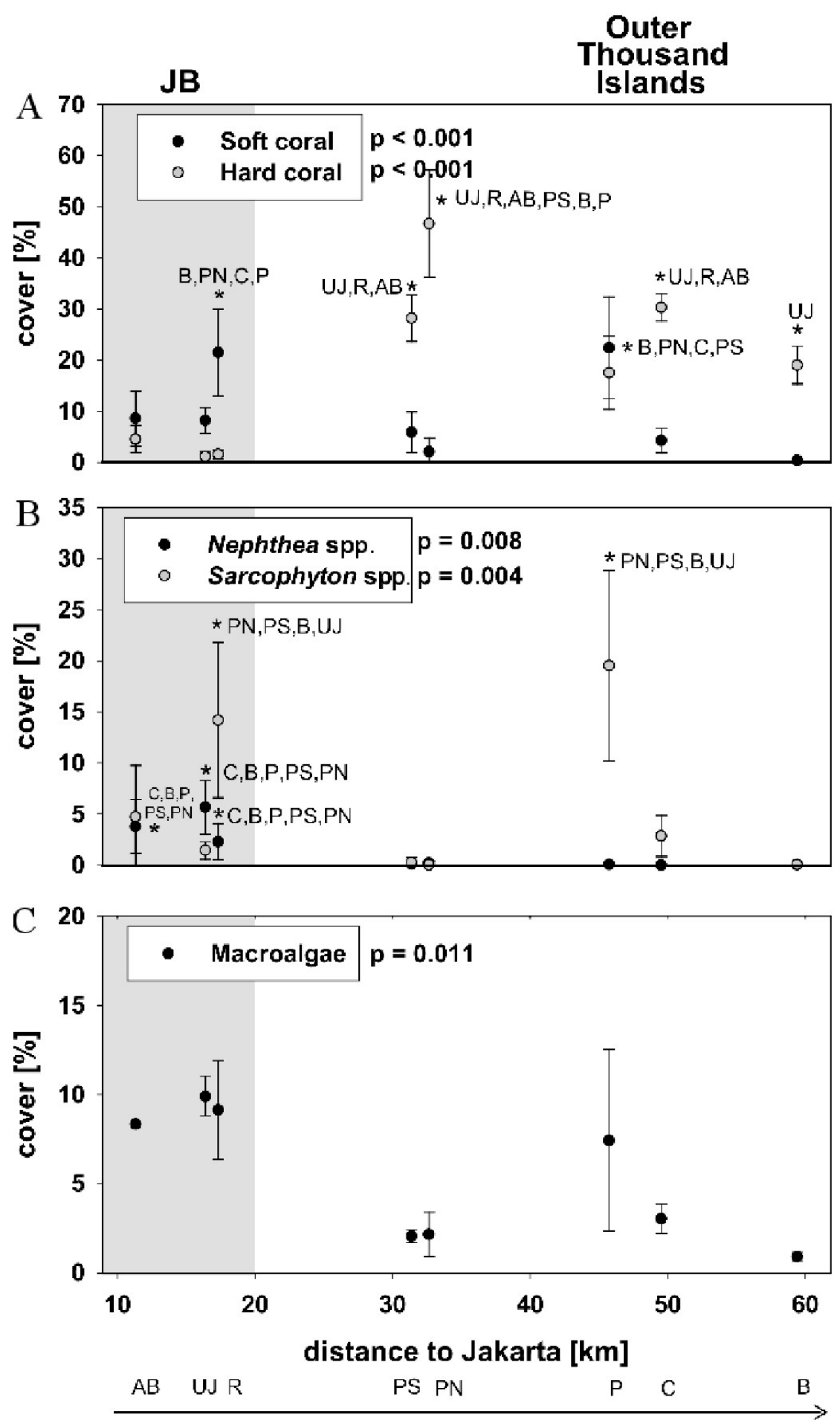

Fig. 2. Live benthic cover. Mean cover $( \pm \mathrm{SD})$ for hard and soft corals $(A)$, the two soft coral 989 genera Sarcopyhton spp. and Nephthea spp. (B) as well as macroalgae (C) for sites along the 990 Thousand Islands ( $\mathrm{x}$-axis refers to distance to Jakarta). $p$-values $(p>0.05$; one.way ANOVA) 991 and significant post hoc results $(p>0.05$; Student-Newman-Keuls) for differences among sites 992 are given for each group. Consider different scales on y-axis. Study sites: AB = Ayer Besar, UJ = 
993 Untung Jawa, $\mathrm{R}=$ Rambut, $\mathrm{PS}=$ Pari South, $\mathrm{PN}=$ Pari North, $\mathrm{P}=$ Panggang, $\mathrm{C}=$ Congkak, $\mathrm{B}=$ 994 Bira.

995

996

A

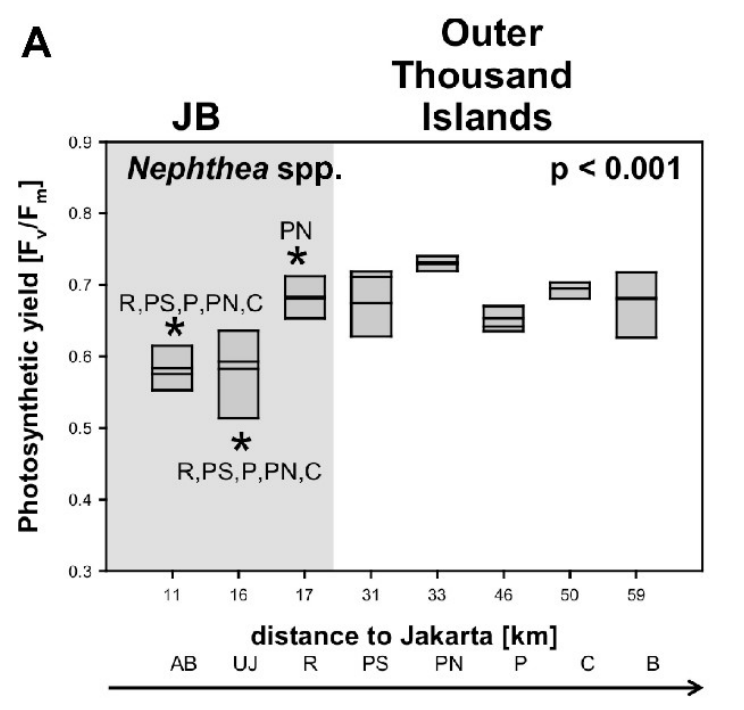

B

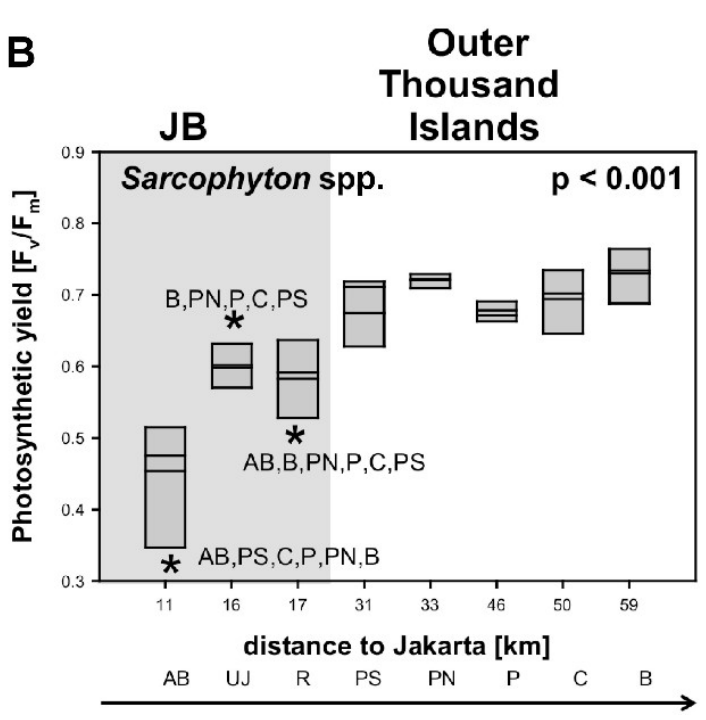

998

999

1000

1001

1002

1003

1004

1005

1006

1007

1008

1009

1010

1011

1012

Fig. 3. Mean photosynthetic yield $\left(\mathrm{F}_{\mathrm{v}} / \mathrm{F}_{\mathrm{m}}\right)$ of Nephthea spp. (A) and Sarcophyton spp. (B) for sites along the Thousand Islands ( $\mathrm{x}$-axis refers to distance to Jakarta). $p$-values $(p>0.05$; one.way ANOVA) and significant post hoc results ( $p>0.05$; Student-Newman-Keuls) for differences among sites are given for each group. $\mathrm{AB}=$ Ayer Besar, $\mathrm{UJ}=$ Untung Jawa, $\mathrm{R}=$ Rambut, $\mathrm{PS}=$ Pari South, $\mathrm{PN}=$ Pari North, $\mathrm{P}=$ Panggang, $\mathrm{C}=$ Congkak, $\mathrm{B}=$ Bira.

(1)


A

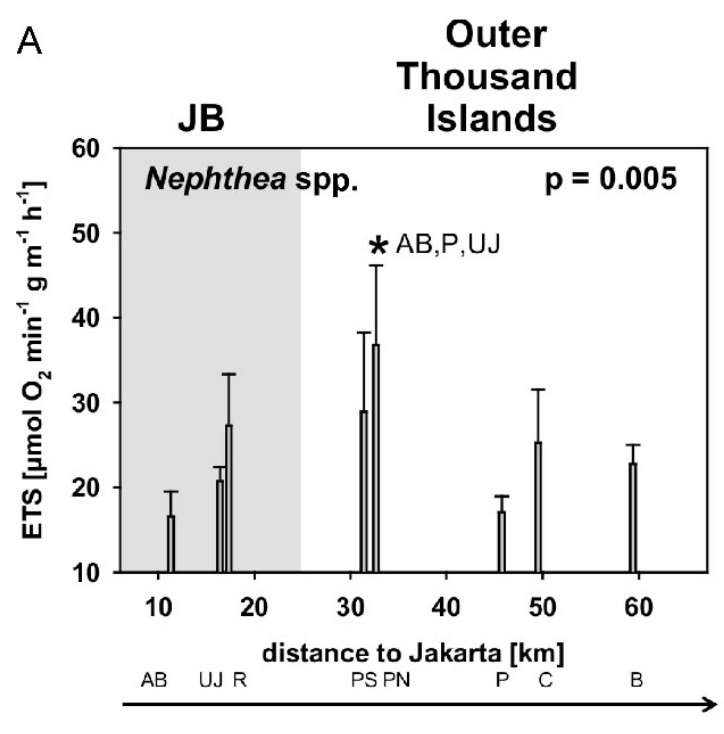

B

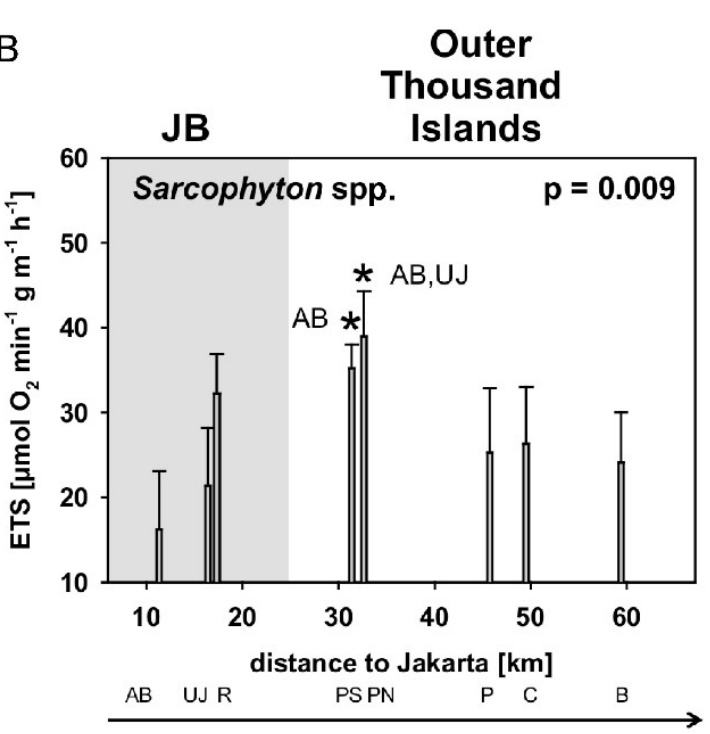

1014

1015

1016

1017

1018

1019

1020

1021

1022

1023

1024

1025

1026

1027

1028

1029

Fig. 4. Mean electron transport system (ETS) activity Nephthea spp. (A) and Sarcophyton spp. (B) for sites along the Thousand Islands (x-axis refers to distance to Jakarta). $p$-values ( $p>0.05$; one.way ANOVA) and significant post hoc results $(p>0.05$; Student-Newman-Keuls) for differences among sites are given for each group. $\mathrm{AB}=$ Ayer Besar, $\mathrm{UJ}=$ Untung Jawa, $\mathrm{R}=$ Rambut, $\mathrm{PS}=$ Pari South, $\mathrm{PN}=$ Pari North, $\mathrm{P}=$ Panggang, $\mathrm{C}=$ Congkak, $\mathrm{B}=$ Bira.

(1)

(1)


A Sarcophyton spp.

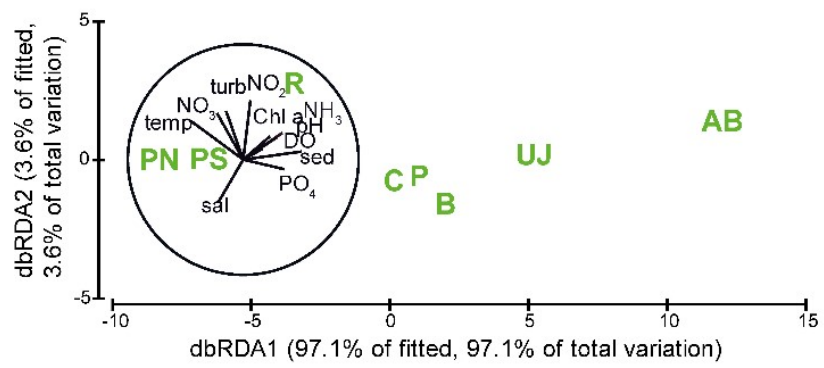

C Nephthea spp.

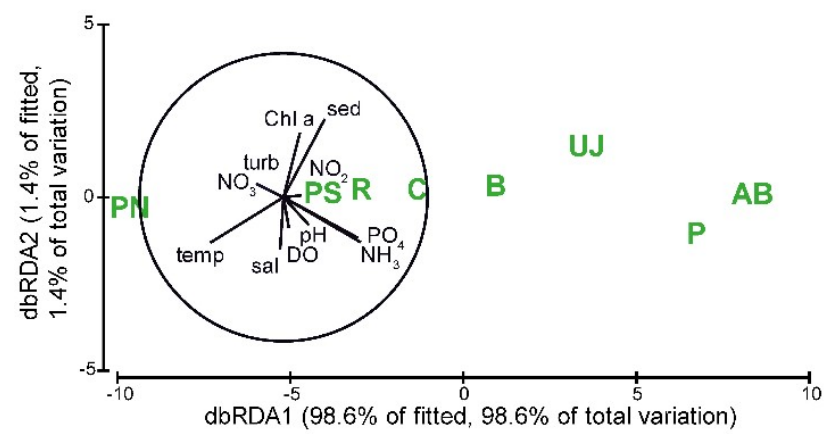

B Sarcophyton spp.

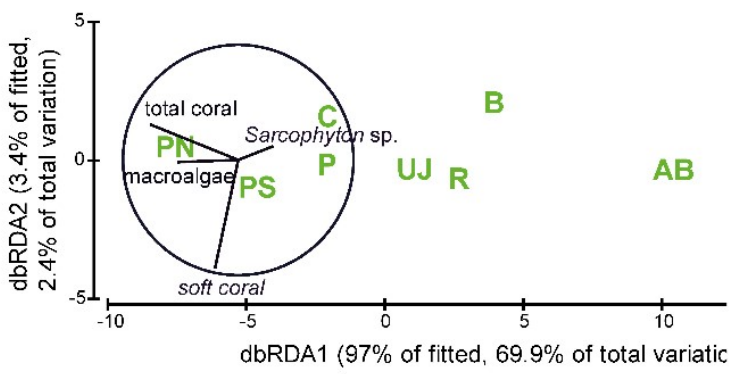

D Nephthea spp.

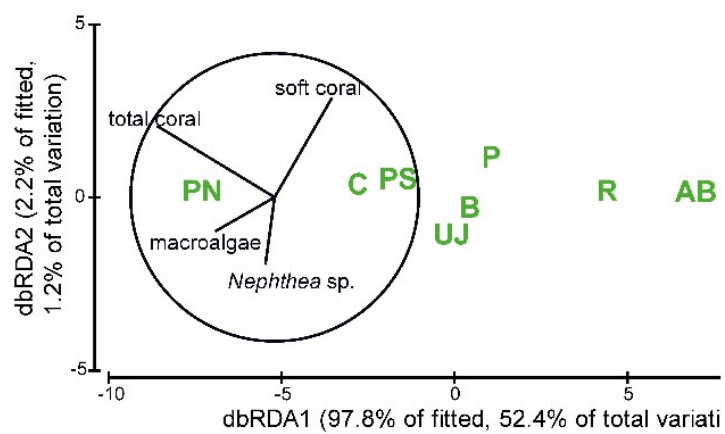

1030

1031

1032

1033

1034

1035

1036

1037

1038

1039

1040

1041

1042

1043

1044

1045

1046

1047

1048

Fig. 5. Visualization of the metabolic condition indicated by photosynthetic yield $\left(F_{v} / F_{m}\right)$ and electron transport system (ETS) activity of the two soft coral genera Sarcophyton spp. and Nephthea spp. based on distance-based redundancy analysis (dbRDA). Water quality factors (A: Sarcophyton spp. and C: Nephthea spp.) and benthic factors (B: Sarcophyton spp. and D: Nephthea spp.) are overlain for both genera. Study sites: $\mathrm{AB}=$ Ayer Besar, $\mathrm{UJ}=$ Untung Jawa, $\mathrm{R}$ $=$ Rambut, $\mathrm{PS}=$ Pari South, $\mathrm{PN}=$ Pari North, $\mathrm{P}=$ Panggang, $\mathrm{C}=$ Congkak, $\mathrm{B}=$ Bira . 


\section{Supplementary Information}

1052 Table S1. Comparison of electron transport system (ETS) activity, photosynthetic yield $\left(\mathrm{F}_{\mathrm{v}} / \mathrm{F}_{\mathrm{m}}\right)$ 1053 and benthic cover between sites (One-Way Anova and post hoc Student Newman-Keuls 1054 Method). Study sites: $\mathrm{AB}=$ Ayer Besar, UJ = Untung Jawa, R = Rambut, PS = Pari South, PN = 1055 Pari North, $\mathrm{P}=$ Panggang, $\mathrm{C}=$ Congkak, $\mathrm{B}=$ Bira. Replicate number varied between the two 1056 genera for the ETS-activity: $\mathrm{n}=5$ for Nephthea spp. (except for the sites UJ, R: $\mathrm{n}=4$ and PN, B: $1057 \mathrm{n}=3$ ) and $\mathrm{n}=4$ for Sarcophyton spp. (except for the sites PN,C, B: $\mathrm{n}=3$ ). For photosynthetic 1058 yield $\mathrm{n}=7$ per fragment was used (except for the sites R (Sarcophyton spp. and Nephthea spp.) 1059 with $\mathrm{n}=6$ and UJ (Sarcophyton spp.) with $\mathrm{n}=4$ )

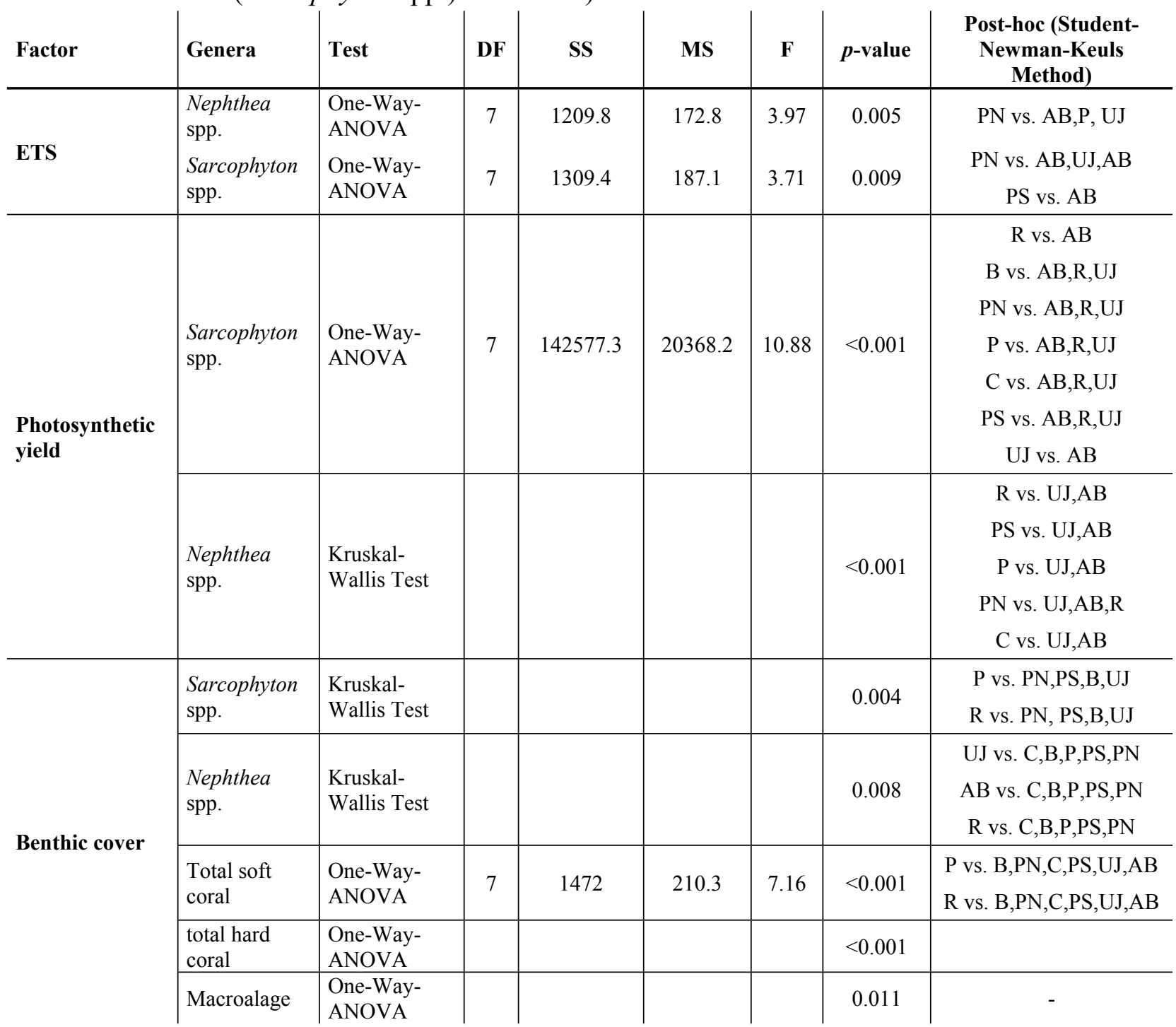


1060

1061

1062 